\title{
Geometric and Electronic Structure Contributions to Function in Non-Heme Iron Enzymes
}

\author{
Edward I. Solomon ${ }^{*}$, Kenneth M. Light, Lei V. Liu, Martin Srnec, and Shaun D. Wong \\ Department of Chemistry, Stanford University, Stanford, CA 94305-5080, U. S. A
}

\section{Conspectus}

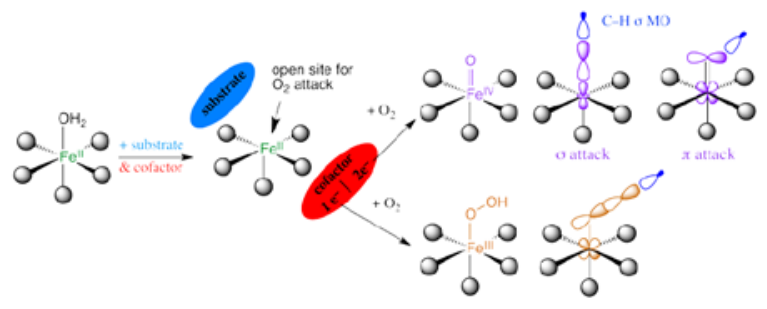

Mononuclear non-heme $\mathrm{Fe}$ (NHFe) enzymes play key roles in antibiotic biosynthesis, hypoxic response, DNA repair, anticancer therapy and many other biological processes. On a molecular level these enzymes catalyze a diverse range of oxidation reactions, including hydroxylation, halogenation, ring closure, desaturation and electrophilic aromatic substitution (EAS). Most of these enzymes use an $\mathrm{Fe}^{\mathrm{II}}$ site to activate dioxygen. These ferrous active sites had been inaccessible to traditional spectroscopic methods. A methodology has been developed that provides detailed geometric and electronic structure insight for these $\mathrm{NHFe}^{\mathrm{II}}$ active sites. This has defined a general mechanistic strategy utilized by a wide range of these enzymes to control $\mathrm{O}_{2}$ activation by $\mathrm{Fe}^{\mathrm{II}}$ coordination unsaturation only in the presence of cosubstrates to limit autooxidation and self-hydroxylation. Depending on the type of enzyme, $\mathrm{O}_{2}$ activation either involves a $2 \mathrm{e}^{-}$reduced $\mathrm{Fe} \mathrm{FII}_{-}^{\mathrm{IIOOH}}$ intermediate or a $4 \mathrm{e}^{-}$reduced $\mathrm{Fe}^{\mathrm{IV}}=\mathrm{O}$ intermediate. The nature of these intermediates has been defined in terms of geometric structure using nuclear resonance vibrational spectroscopy (NRVS) and electronic structure using magnetic circular dichroism (MCD) to define the frontier molecular orbitals (FMOs) that control reactivity.

For Fe $\mathrm{Fe}^{\mathrm{III}}-\mathrm{OOH}$ intermediates the anticancer drug Activated Bleomycin is shown to be the nonheme $\mathrm{Fe}$ analog of compound 0 in heme (e.g. P450) chemistry but undergoes different reactivity where the low-spin (LS) Fe ${ }^{\mathrm{III}}-\mathrm{OOH}$ can directly abstract an $\mathrm{H}$ atom from DNA. It is also shown that the transition states of $\mathrm{LS}$ and high-spin (HS) Fe $\mathrm{F}^{\mathrm{III}}-\mathrm{OOH}$ are fundamentally different in that the former goes through a hydroxyl radical while the latter is activated for EAS without O-O cleavage, which is important in one class of NHFe enzymes that utilizes a $\mathrm{HS} \mathrm{Fe}^{\mathrm{III}}-\mathrm{OOH}$ intermediate in dioxygenation.

For $\mathrm{Fe}^{\mathrm{IV}}=\mathrm{O}$ intermediates the $\mathrm{LS}$ form is shown to have a $\pi$-type FMO activated for attack perpendicular to the $\mathrm{Fe}-\mathrm{O}$ bond while the HS form (present in the NHFe enzymes) has both $\pi$ and $\sigma$ FMOs that are activated for attack both perpendicular to and along the $\mathrm{Fe}-\mathrm{O}$ bond, respectively. For the NHFe enzymes these $\pi v s \sigma$ FMOs direct reactivity for EAS $v s \mathrm{H}$-atom abstraction, and for the latter halogenation $v s$ hydroxylation.

This study emphasizes that experimental spectroscopy is critical in evaluating the results of electronic structure calculations and thus key to bridging structure and reactivity with mechanism. 


\section{Introduction}

Mononuclear non-heme Fe (NHFe) enzymes play key roles in metabolic pathways, hypoxic response, DNA repair, natural product and antibiotic synthesis, and bioremediation. 1,2 Mutations in a number of these enzymes lead to disease states such as phenylketonuria in the case of phenylalanine hydroxylase. The NHFe antibiotic Bleomycin (BLM) is a key drug used in treating head, neck, and testicular cancers. At a molecular level these NHFe sites catalyze a variety of oxidation reactions that include $\mathrm{H}$-atom abstraction for hydroxylation, halogenation, desaturation or ring closure of a substrate and electrophilic aromatic substitution (EAS) for mono- or dioxygenation. As presented in Table 1, these can be broadly divided into two classes. The lipoxygenases and intradiol dioxygenases use a highspin (HS) $\mathrm{NHFe}^{\mathrm{III}}$ center to activate singlet organic substrates for the spin-forbidden reaction with ${ }^{3} \mathrm{O}_{2}$. However, most $\mathrm{NHFe}$ enzymes use a $\mathrm{HS} \mathrm{NHFe}{ }^{\mathrm{II}}$ center to activate $\mathrm{O}_{2}$. The latter group divides into six subclasses (Table 1A). For the pterin- and a-ketoglutarate (aKG)-dependent enzymes the cofactor and $\mathrm{Fe}^{\mathrm{II}}$ each supply two electrons to reduce $\mathrm{O}_{2}$ to form an $S=2 \mathrm{Fe}^{\mathrm{IV}}=\mathrm{O}$ intermediate. ${ }^{3}$ For the pterin family $\mathrm{Fe}^{\mathrm{IV}}=\mathrm{O}$ catalyzes EAS while in the aKG family this ferryl intermediate reacts with substrate via $\mathrm{H}$-atom abstraction. For the extradiol dioxygenases two electrons are supplied by the catecholate substrate to reduce $\mathrm{O}_{2}$ and form a peroxy-quinone-bridged $\mathrm{Fe}^{\mathrm{II}}$ intermediate. ${ }^{4}$ In the Rieske dioxygenases (RDOs), the $\mathrm{Fe}_{2} \mathrm{~S}_{2}$ Rieske center is bridged through an $\mathrm{H}$-bond to the $\mathrm{Fe}^{\mathrm{II}}$ catalytic site and together these transfer two electrons to activate $\mathrm{O}_{2}$ via a high-spin Fe $\mathrm{F}^{\mathrm{III}}-\mathrm{OOH}$ for cis-dioxygenation of an organic substrate. ${ }^{4}$ There is also a group of $\mathrm{NHFe}^{\mathrm{II}}$ enzymes (represented by isopenicillin-N-synthase, IPNS, in Table 1A) that bind non-redox-active substrates and use $\mathrm{O}_{2}$ for either the two-electron or four-electron oxidation/oxygenation of the substrate. In IPNS this reaction appears to involve the initial, thermodynamically-difficult one-electron reduction of $\mathrm{O}_{2}$ to form a $\mathrm{HS} \mathrm{Fe} \mathrm{FII}^{\mathrm{III}} \mathrm{O}_{2}{ }^{{ }^{-}}$intermediate. $^{5}$

Almost all the NHFe ${ }^{\mathrm{II}}$ enzymes utilize a 2-His-1-carboxylate facial triad ligand set of protein residues to bind the $\mathrm{Fe}^{\mathrm{II}}$, with additional coordination positions (occupied by waters in the resting enzyme) that are potentially available for $\mathrm{O}_{2}$, substrate and cofactor binding. The drug BLM also has a NH ligand set (vide infra). BLM uses $\mathrm{Fe}^{\mathrm{II}}$ to bind $\mathrm{O}_{2}$ and with one exogenous electron forms activated BLM (ABLM), a low-spin (LS) Fe ${ }^{\mathrm{III}}-\mathrm{OOH}$ site that $\mathrm{H}$ atom abstracts from DNA for strand cleavage in its anti-cancer activity. ABLM is the NHFe analog of compound 0 in $\mathrm{P} 450$ heme chemistry (also a LS Fe ${ }^{\mathrm{III}}-\mathrm{OOH}$ ). The latter goes on to protonate and cleave heterolytically to generate compound $\mathrm{I}\left(\mathrm{a}\left(\mathrm{Por}^{\circ-}\right) \mathrm{Fe}^{\mathrm{IV}}=\mathrm{O}\right.$ species $\left.{ }^{6}\right)$ that $\mathrm{H}$-atom abstracts from strong $\mathrm{C}-\mathrm{H}$ bonds of substrates.

In this Account we focus on the NHFe ${ }^{\mathrm{II}}$ enzymes and BLM (see ref. 7 for a perspective on $\mathrm{NHFe}^{\mathrm{III}}$ substrate-activating enzymes). We first consider the geometric and electronic structures of the resting $\mathrm{Fe}^{\mathrm{II}}$ centers and their interactions with substrates that turn on $\mathrm{O}_{2}$ activation. The $\mathrm{NHFe}^{\mathrm{II}}$ active site has been challenging to study as the $\pi-\pi^{*}$ transitions of heme Fe are absent, and these $d^{6}$ ions have an $S=2$ ground state, which is an integer-spin, non-Kramers system where all the spin degeneracy is eliminated by the low-symmetry protein environment and thus produces no EPR signal at X-band. The ferrous active sites in these enzymes have been made accessible through the development of a near-IR (NIR) variable-temperature, variable-field magnetic circular dichroism (VTVH MCD) spectroscopic methodology. This has led to the determination of a general mechanistic strategy used by the NHFe ${ }^{\mathrm{II}}$ enzymes in Table 1A. This methodology is surveyed in section 1.1 and used to develop structure/function correlations in section 1.2. For the RDOs and $\mathrm{BLM}$, the $\mathrm{O}_{2}$ is activated at the hydroperoxo level. In section 2 we consider how the reactivity of the LS Fe ${ }^{\mathrm{III}}-\mathrm{OOH}$ of the NHFe site in ABLM relates to that of compound 0 in $\mathrm{P} 450$, and the activation of $\mathrm{HS} \mathrm{Fe} \mathrm{III}^{\mathrm{II}} \mathrm{OOH}$ for EAS as in the RDOs. The emphasis here is 
on the frontier molecular orbitals (FMOs) and how they change with spin. For the aKG- and pterin-dependent NHFe enzymes, the oxygen intermediate key to reactivity is the HS $\mathrm{Fe}^{\mathrm{IV}}=\mathrm{O}$ species. In section 3.1 we use spectroscopy on structurally-defined LS and HS $\mathrm{Fe}^{\mathrm{IV}}=\mathrm{O}$ model complexes to experimentally determine the FMOs that are important for reactivity, and in section 3.2 we consider how these FMOs direct H-atom abstraction $v s$. EAS and halogenation $v s$. hydroxylation.

\section{Ferrous active sites}

\subsection{NIR VTVH MCD Methodology}

From ligand field theory (LFT), an $O_{\mathrm{h}} \mathrm{Fe}^{\mathrm{II}} d^{6} \mathrm{HS}$ site has a ${ }^{5} T_{2 \mathrm{~g}}$ ground state and at an energy $10 D q$ above this is the spin-allowed ${ }^{5} E_{\mathrm{g}}$ excited state, where for the N/O facial triad and $\mathrm{H}_{2} \mathrm{O}$ ligation $10 D q \approx 10,000 \mathrm{~cm}^{-1}{ }^{1}$ These states are orbitally-degenerate and will split in energy in the low-symmetry protein environment. For a six-coordinate (6C) $\mathrm{Fe}^{\mathrm{II}}$ site the ${ }^{5} E_{g}$ can split by up to $2000 \mathrm{~cm}^{-1}$. Loss of one ligand to form a five-coordinate (5C) square pyramidal $\mathrm{Fe}^{\mathrm{II}}$ center leads to a large ${ }^{5} E$ splitting, producing $\mathrm{LF}$ transitions in the $>10,000 \mathrm{~cm}^{-1}$ and $\approx 5000 \mathrm{~cm}^{-1}$ regions. In a $5 \mathrm{C}$ trigonal bipyramidal structure the LF changes and the transitions shift to $<10,000 \mathrm{~cm}^{-1}$ and $<5000 \mathrm{~cm}^{-1}$, and in a $4 \mathrm{C}$ distorted tetrahedral site, since $10 D q\left(T_{\mathrm{d}}\right)=-4 / 910 \mathrm{Dq}\left(\mathrm{O}_{\mathrm{h}}\right)$, there are only LF transitions in the $\approx 5000-7000 \mathrm{~cm}^{-1}$ region. Thus from Figure 1A the energy splittings of the $d$ orbitals and associated $d \rightarrow d$ transitions are very sensitive to the $\mathrm{LF}$ of the $\mathrm{Fe}^{\mathrm{II}}$ site.

Since $d \rightarrow d$ transitions are parity-forbidden, they are weak in absorption (abs.) and since these are in the NIR spectral region where intense vibrations from the protein and buffer contribute, these cannot be studied by abs. spectroscopy. However, since the ground state is $S=2$, the sites can be directly studied by NIR MCD at low temperature (LT) where the " $C$ term" MCD signals of paramagnetic centers are orders of magnitude larger than those of the diamagnetic background. The LT MCD spectra of $>20$ structurally-defined $\mathrm{Fe}^{\mathrm{II}}$ complexes with different coordination environments have been studied and found to be as predicted by LFT as shown in Figure 1B. ${ }^{1}$

From Figure 2A the threefold-degenerate ${ }^{5} T_{2}$ ground state also splits in energy in the lowsymmetry protein environment, reflecting differences in $d \pi$ interactions with the ligands. This can be studied directly by VTVH MCD. ${ }^{1}$ A HS Fe ${ }^{\mathrm{II}}$ center will produce a set of nested saturation magnetization curves as shown in Figure 2B. This nesting is due to the nonlinear energy splitting and mixing of the $M_{\mathrm{S}}$ sublevels of the $S=2$ ground state, and fitting these data gives the ground-state splitting $\left(\delta, g_{\|}\right)$that in turn is determined by the axial $(\Delta)$ and rhombic (V) splittings of the $d \pi$ orbitals. Thus for the NHFe ${ }^{\mathrm{II}}$ sites we are able to experimentally determine the energies of the five $d$ orbitals (Figure 1A), which reflect the active site geometric and electronic structure.

\subsection{General Mechanistic Strategy}

The above methodology has been applied to define structure/function correlations over a number of $\mathrm{NHFe}^{\mathrm{II}}$ enzymes in each of the subclasses in Table 1A. The data presented in Figure 3 on the pterin-dependent enzyme phenylalanine hydroxylase (PAH) (with Caradonna et al. $^{8}$ ) are representative of the behavior we observe for all three pterindependent enzymes and in general for all the subclasses of NHFe ${ }^{\mathrm{II}}$ enzymes. Resting PAH exhibits the LT MCD spectrum in black, showing two LF transitions in the $\sim 10,000 \mathrm{~cm}^{-1}$ region split by $\sim 2,000 \mathrm{~cm}^{-1}$. Thus the resting $\mathrm{Fe}^{\mathrm{II}}$ site is $6 \mathrm{C}$. Upon addition of phenylalanine substrate the blue spectrum is obtained, showing a slightly perturbed $6 \mathrm{C} \mathrm{Fe}$ iI site. Addition of pterin to the resting $\mathrm{Fe}^{\mathrm{II}}$ enzyme produces the green LT MCD spectrum showing that the pterin cofactor does not bind to the $\mathrm{Fe}^{\mathrm{II}}$. Importantly when both pterin and substrate are 
added to resting PAH, the LT MCD spectrum in red is obtained with one LF transition at $\approx 10,000 \mathrm{~cm}^{-1}$ and one in the $\approx 5,000 \mathrm{~cm}^{-1}$ region. Also, the VTVH MCD saturation magnetization curves change dramatically upon substrate-plus-cofactor binding to resting $\mathrm{Fe}^{\mathrm{II}} \mathrm{PAH}$ (Figure 3B). These data give the experimental LF splittings of the five $d$ orbitals in Figure $3 \mathrm{C}$. In the resting, substrate-bound and only-cofactor-bound $\mathrm{Fe}^{\mathrm{II}}$ forms, $10 D q$ is large and there is only a limited splitting of $E$ and $T_{2}$ orbital degeneracies, reflecting $6 \mathrm{C}$ sites. Alternatively when both substrate and cofactor are bound to the enzyme, $10 D q$ greatly decreases and there is a large splitting of $E$ and $T_{2}$ degeneracies, all showing that the $\mathrm{Fe}^{\mathrm{II}}$ active site becomes $5 \mathrm{C}$ upon binding both cosubstrates.

Parallel NIR VTVH MCD studies have been performed over a range of other NHFe ${ }^{\mathrm{II}}$ enzymes which have led to the general mechanistic strategy used by this class of enzymes shown in Figure 4. The resting $\mathrm{Fe}^{\mathrm{II}}$ state and sites with either substrate or cofactor bound are $6 \mathrm{C}$ and relatively stable to reaction with $\mathrm{O}_{2}$, which at this stage would lead to uncoupled turnover and potentially self-hydroxylation. However, when both the substrate and the cofactor are bound to the enzyme the $\mathrm{Fe}^{\mathrm{II}}$ site becomes $5 \mathrm{C}$, with an open coordination position for $\mathrm{O}_{2}$ activation.

This $6 \mathrm{C} \rightarrow 5 \mathrm{C}$ conversion involves the loss of an $\mathrm{H}_{2} \mathrm{O}$ ligand. The molecular basis for the substrate-induced $\mathrm{H}_{2} \mathrm{O}$ loss has been defined (in collaboration with Knapp et al. ${ }^{9}$ ) in FIH (involved in hypoxic signaling) and has been found to involve both steric clashes between $\mathrm{H}_{2} \mathrm{O}$ and substrate in the $6 \mathrm{C}$ form and stabilization of the $5 \mathrm{C}$ form through $\mathrm{H}$-bonding to the facial triad carboxylate (Figure 5A).

With respect to the facial-triad carboxylate, there are interesting differences among the different subclasses that reflect second-sphere interactions that are important for $\mathrm{O}_{2}$ reactivity. For the aKG-dependent and extradiol enzymes the cofactor/cosubstrate binds bidentate to $\mathrm{Fe}^{\mathrm{II}}$. As $\mathrm{O}_{2}$ must also bind to $\mathrm{Fe}^{\mathrm{II}}$ for catalysis, three coordination sites are needed for reactivity (Figure 5B, left). However, for a $5 \mathrm{C} \mathrm{Fe}^{\mathrm{II}}$ site the facial-triad carboxylate will switch to bidentate coordination (Figure 5B, right), which would prevent catalysis. ${ }^{9}$ Extradiol dioxygenases and aKG-dependent enzymes avoid this by having a second-sphere residue available to $\mathrm{H}$-bond to the facial-triad carboxylate. For the pterindependent and RDO enzymes, neither substrate nor cofactor binds to the $\mathrm{Fe}^{\mathrm{II}}$. Members of these subclasses do not have a second-sphere residue H-bond to the facial triad carboxylate; thus it coordinates to the $\mathrm{Fe}^{\mathrm{II}}$ in a bidentate mode, allowing $\mathrm{O}_{2}$ to bind in a single orientation for proper reactivity (Figure 5B, right). For pterin-dependent enzymes, $\mathrm{O}_{2}$ must bind in an end-on fashion for bridging between $\mathrm{Fe}^{\mathrm{II}}$ and the pterin cofactor, cleave, and rearrange for reaction with substrate. For Rieske dioxygenases, a side-on bidentate binding mode for $\mathrm{O}_{2}$ is required for formation of the reactive intermediate.

\section{Fe $\mathrm{e}^{\mathrm{IIL}}-\mathrm{hydroperoxy}$ intermediates}

$\mathrm{Fe}^{\mathrm{III}}-\mathrm{OOH}$ intermediates are important in ABLM which is $\mathrm{LS}(S=1 / 2)$ and in the RDOs which are HS $(S=5 / 2)$. ABLM is the NHFe intermediate closest to that in heme chemistry and in section 2.1 we contrast their reactivity. In section 2.2 we evaluate how spin state influences the FMOs and affects the transition state (TS), and its relation to function in the RDOs.

\subsection{Low-Spin Non-Heme vs. Heme}

(BLM)Fe $\mathrm{Fe}^{\mathrm{II}}$ binds $\mathrm{O}_{2}$ and takes up an exogenous $e^{-}$to form ABLM, a LS ferrichydroperoxide (Figure 6). ${ }^{10} \mathrm{ABLM}$ is the intermediate before $\mathrm{H}$-atom abstraction from the C4' position of DNA. ${ }^{11}$ In the heme analog, compound 0 of P450, this LS Fe ${ }^{\mathrm{III}}-\mathrm{OOH}$ protonates and heterolytically cleaves to form compound $\mathrm{I}$, an $\mathrm{Fe}^{\mathrm{IV}}=\mathrm{O}$ porphyrin radical, 
that $\mathrm{H}$-atom abstracts from strong $\mathrm{H}-\mathrm{C}$ bonds. There has been significant interest in whether ABLM parallels heme chemistry to generate an unobserved compound I analog that does the DNA cleavage. Thus, we used calculations supported by the spectroscopic data to elucidate the relative energies of the protonation/heterolytic cleavage reactions in ABLM and compound 0 in P450. From Table 2, this reaction is calculated to be $71 \mathrm{kcal} / \mathrm{mol}$ less favorable in ABLM relative to P450 and endergonic by $13 \mathrm{kcal} / \mathrm{mol} .{ }^{12}$ This reflects the fact that delocalization of the hole over the $\pi$ system of the porphyrin and its -2 charge facilitate ligand oxidation in heme relative to a non-heme ligand set, as evidenced by the muchhigher-energy of the lignd-to-metal charge transfer (LMCT) transitions of (BLM)Fe $\mathrm{Fe}^{\mathrm{III}}$ as compared to heme (Figure 7).

These considerations lead to the alternative hypothesis of direct $\mathrm{H}$-atom abstraction from the substrate by ABLM. ${ }^{12}$ From the calculations listed in Table 2, this reaction is $20 \mathrm{kcal} / \mathrm{mol}$ more favorable than the heterolytic cleavage reaction and exergonic by $7 \mathrm{kcal} / \mathrm{mol}$.

However, a computational study considering the peroxo-shunt reaction argued for a $(\mathrm{BLM}) \mathrm{Fe}^{\mathrm{III}}-\mathrm{H}_{2} \mathrm{O} \rightarrow(\mathrm{BLM}) \mathrm{Fe}^{\mathrm{III}}-\mathrm{H}_{2} \mathrm{O}_{2}$ conversion, and the presence of the additional proton would make the heterolytic cleavage more favorable by $15 \mathrm{kcal} / \mathrm{mol}$, comparable to direct $\mathrm{H}$-atom abstraction by (BLM)Fe $\mathrm{F}^{\mathrm{III}}-\mathrm{OOH}{ }^{13}$

Thus it was necessary to experimentally determine the nature of the axial ligands in (BLM)Fe ${ }^{\mathrm{III}}$ and ABLM. Since ABLM is unstable in a laser, we turned to nuclear resonance vibrational spectroscopy (NRVS). From Figure 8, the spectrum for (BLM)Fe $\mathrm{III}^{\mathrm{II}}$ shows an $\mathrm{H}_{2}{ }^{18} \mathrm{O}$ isotope-sensitive vibration at $567 \mathrm{~cm}^{-1}$ which, combined with an EXAFS distance of $1.86 \AA$ and computational modeling (Figure 84 , bottom), assigns the axial ligand as hydroxide.$^{10}$ It also exhibits a dominant feature at $407 \mathrm{~cm}^{-1}$, which reflects the degenerate pair of trans-axial bends (Figure 8C) that has dominant Fe motion. In going to the NRVS spectrum of ABLM, this pair splits into two peaks at 438 and $398 \mathrm{~cm}^{-1}$ and an additional feature is present at $328 \mathrm{~cm}^{-1}$. This trans-axial splitting is only reproduced by the Fe $\mathrm{Fe}^{\mathrm{III}}$ $\mathrm{OOH}$ structure of ABLM where the $328 \mathrm{~cm}^{-1}$ peak is the $\mathrm{Fe}-\mathrm{O}-\mathrm{O}$ bend and this mixes with the in-plane trans-axial bend leading to the peak splitting.

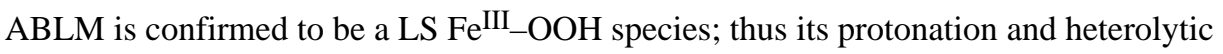
cleavage to produce a heme-type compound I is unfavorable by $20 \mathrm{kcal} / \mathrm{mol}$ relative to its direct $\mathrm{H}$-atom abstraction from DNA, Table 2. The direct reaction of ABLM requires that DNA participate in the TS. DNA does in fact accelerate this reaction by $\sim 2.5$ times and changes ABLM's decay kinetics from having a relatively-small primary KIE $(3.6 \pm 0.9$, from self-decay) to a large secondary KIE with DNA $(1.7 \pm 0.2$, non-exchangeable $\mathrm{H}-\mathrm{C} 4$ ' group). ${ }^{14}$

These experimental data were modeled with a 2D potential energy surface (PES) for the $\mathrm{H}$ atom abstraction from the $\mathrm{H}-\mathrm{C}$ bond of a substrate by ABLM (Figure 9A). ${ }^{15}$ A TS was found that reproduces experiment with an $E_{\mathrm{a}}$ of $13 \mathrm{kcal} / \mathrm{mol}$, about half that calculated for heterolytic cleavage and $\mathrm{H}$-atom abstraction. The TS for direct Fe $\mathrm{F}^{\mathrm{III}}-\mathrm{OOH}$ attack on DNA also reproduces the small primary and large secondary KIEs that reflect a TS that is late in $\mathrm{O}-\mathrm{O}$ cleavage but early in $\mathrm{H}$-atom abstraction (Figure 9B).

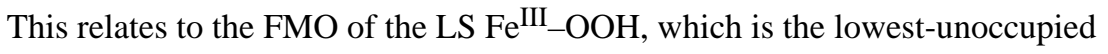
hydroperoxide $\sigma^{*}$ orbital. From Figure 9C, elongation of the $\mathrm{O}-\mathrm{O}$ to the TS greatly weakens the peroxo $\sigma / \sigma^{*}$ interaction and allows its $\alpha$ - and $\beta$-spin holes to polarize: one on the distal $O$ making this an $\mathrm{OH}^{*}$ radical that is efficient in $\mathrm{H}$-atom abstraction, and the other localizes on the proximal $\mathrm{O}$ generating an $\mathrm{Fe}^{\mathrm{IV}}=\mathrm{O}$ species. The latter is effective in performing a second 
H-atom abstraction from DNA, leading to double-strand cleavage important for BLM's anticancer activity.

\subsection{Low-Spin to High-Spin Fe ${ }^{\text {III-OOH FMOs }}$}

In going to the RDOs the Fe $\mathrm{III}^{\mathrm{IIO}} \mathrm{OOH}$ intermediate is $\mathrm{HS}^{4}$ Spectroscopic studies were performed (with Nam and co-workers ${ }^{16}$ ) on $S=1 / 2$ (N4Py)Fe ${ }^{\mathrm{III}}-\mathrm{OOH}$ and the $S=5 / 2$ (TMC)Fe ${ }^{\mathrm{III}}-\mathrm{OOH}$ models and correlated to electronic-structure calculations to understand differences in their reactivities. For LS Fe ${ }^{\mathrm{III}}-\mathrm{OOH}$ the TS for $\mathrm{H}$-atom abstraction is again late in $\mathrm{O}-\mathrm{O}$ cleavage, generating an $\mathrm{OH}^{\bullet}$ for $\mathrm{H}$-atom abstraction.

In contrast, in the $\mathrm{HS}^{16} \mathrm{Fe}^{\mathrm{III}}-\mathrm{OOH}$ complex the TS is early in $\mathrm{O}-\mathrm{O}$ cleavage and later in $\mathrm{H}$ atom abstraction, Figure 10A. The origin of this difference in TSs is the spin-state dependence of O-O bond homolysis (Figure 10B), where the $\mathrm{HS} \mathrm{Fe}$ III-OOH has an additional $12 \mathrm{kcal} / \mathrm{mol}$ barrier. This derives from the different interactions between redox active orbitals in LS and HS Fe ${ }^{\mathrm{III}}-\mathrm{OOH}$ (Figure $\left.10 \mathrm{C} v s . \mathrm{D}\right){ }^{17}$

The relatively-low barrier for O-O homolysis in the LS system allows generation of an $\mathrm{OH}^{\bullet}$ for $\mathrm{H}$-atom abstraction. Alternatively for the HS Fe ${ }^{\mathrm{III}}-\mathrm{OOH}$ complex, the larger barrier for homolysis leads to a relatively-short $\mathrm{O}-\mathrm{O}$ bond $(1.79 \AA)$ at the TS for H-atom abstraction (Figure 10A). At this TS significant electron density is transferred from the substrate into the

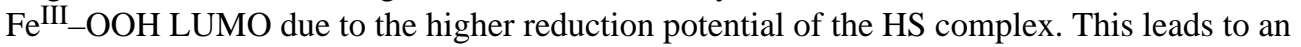
important spin-state dependence of the reaction barrier on the substrate. LS Fe ${ }^{\mathrm{III}}-\mathrm{OOH}$ (eg. ABLM) is favored for $\mathrm{H}$-atom abstraction from strong $\mathrm{H}-\mathrm{C}$ bonds while $\mathrm{HS}$ Fe ${ }^{\mathrm{III}}-\mathrm{OOH}$ is activated for electrophilic attack on substrates without $\mathrm{O}-\mathrm{O}$ bond cleavage. The latter is important for the RDOs where both oxygen atoms of the hydroperoxide are inserted into cis positions of aromatic substrates.

\section{3. $\mathrm{Fe}^{\mathrm{IV}}=0$ intermediates}

For the $\mathrm{aKG}$ and pterin-dependent enzymes the cofactor and $\mathrm{Fe}^{\mathrm{II}}$ each donate $2 e^{-}$to dioxygen to generate $S=2 \mathrm{Fe}^{\mathrm{IV}}=\mathrm{O}$ intermediates. The pterin enzymes perform electrophilic aromatic substitution (EAS); the aKG-dependent enzymes abstract an H-atom, followed by rebound hydroxylation for the facial-triad enzymes, or halogenation in the halogenases where the facial-triad carboxylate is replaced by a halide. In section 3.1 we consider the FMOs available for these reactivities in structurally-defined $S=1$ and $S=2 \mathrm{Fe}^{\mathrm{IV}}=\mathrm{O}$ model complexes. ${ }^{18,19}$ In section 3.2 we extend these FMO concepts to understand the factors that control EAS vs. H-atom abstraction, and for the latter the factors that control hydroxylation $v s$. halogenation.

\subsection{FMOs}

The bonding description of the first structurally-defined $S=1 \mathrm{Fe}^{\mathrm{IV}}=\mathrm{O}$ model complex (TMC)Fe $\mathrm{IV}^{\mathrm{IV}}=\mathrm{O}^{18}$ is shown in Figure 11: at high energy is the $d_{\mathrm{z}^{2}}$ orbital which is strongly $\sigma$ antibonding with the oxo $p_{\mathrm{z}}$, and at lower energy is the Fe $\pi^{*}-d_{\mathrm{xz}, \mathrm{yz}}-$ oxo $p_{\mathrm{x}, \mathrm{y}}$ combination, forming the $d \pi^{*} \beta$ FMOs available for reactivity. These FMOs were studied directly (with Que et al. ${ }^{20}$ ) by using abs. and MCD spectroscopies to probe the $d_{\mathrm{xy}}(n b) \rightarrow d_{\mathrm{xz}, \mathrm{yz}}\left(\pi^{*}\right)$ excitation. The weak, relatively-uninformative abs. band at $\sim 12,000 \mathrm{~cm}^{-1}$ (Figure 12A) results from three overlapping transitions as revealed by VT MCD (Figure 12B). These three transitions have different temperature-dependent MCD behaviors that reflect the different polarizations of the electronic transitions. Importantly, overlapping band I is the negative, sharp band II, the lowest-energy $(x, y)$-polarized $d_{\mathrm{xy}} \rightarrow d_{\mathrm{xz}, \mathrm{yz}} \mathrm{LF}$ transition. Band II directly experimentally probes the $d \pi^{*} \mathrm{FMO}$ of this $\mathrm{Fe}^{\mathrm{IV}}=\mathrm{O}$ complex and shows (from the associated vibrational progression, Figure 12C) a strong $\pi$-antibonding interaction which 
shifts significant $O \mathrm{p} \pi$ character into the $\mathrm{d} \pi^{*}$ orbitals, activating them for electrophilic attack perpendicular to the $\mathrm{Fe}-\mathrm{O}$ bond. ${ }^{20}$

In going from an $S=1$ to an $S=2$ ground state of $\mathrm{Fe}^{\mathrm{IV}}=\mathrm{O}$, a $\beta e^{-}$in $d_{\mathrm{xy}}$ is transferred into the $d_{\mathrm{x}}{ }^{2}-\mathrm{y}^{2}$ orbital. This does not affect the $\mathrm{Fe}^{\mathrm{IV}}=\mathrm{O}$ bond; however, there is a significant effect on the low-lying unoccupied FMOs. From the spin-unrestricted MO diagram in Figure 13, excitation of a $\beta e^{-}$from the $d_{\mathrm{xy}}$ into the $\mathrm{a}-d_{\mathrm{x}}{ }^{2}-\mathrm{y}^{2}$ orbital leads to stabilization of the $\mathrm{a}-$ spin manifold due to the spin polarization associated with differences in exchange. This brings the $\mathrm{a}-d_{\mathrm{z}^{2}} \sigma^{*}$ orbital down to an energy comparable to the $d \pi^{*}$ FMO. However, the $d_{\mathrm{z}^{2}} \sigma^{*}$ has oxo $p_{\mathrm{z}}$ character oriented along the $\mathrm{Fe}-\mathrm{O}$ bond (Figure 13C). Thus, for the $S=2$ $\mathrm{NHFe}^{\mathrm{IV}}=\mathrm{O}$ intermediates there are two low-lying unoccupied FMOs available for $\mathrm{H}$-atom abstraction and EAS: the $\mathrm{d} \pi^{*} F M O$ with oxo $\mathrm{p}_{x, y}$ character perpendicular to the $\mathrm{Fe}-\mathrm{O}$ bond, and the $\mathrm{d} \sigma^{*} F M O$ with oxo $\mathrm{p}_{z}$ character for attack along the $\mathrm{Fe}-\mathrm{O}$ bond.

Studies on the first structurally-defined $S=2 \mathrm{Fe}^{\mathrm{IV}}=\mathrm{O}$ complex $\left(\mathrm{TMG}_{3}\right.$ tren) $\mathrm{Fe}^{\mathrm{IV}}=\mathrm{O}^{19}$ (with Que et $a l .{ }^{21}$ ) revealed relatively-uninformative low-energy weak and high-energy intense abs. bands, but high-information-content LT MCD spectra (Figure 14). The band at $~ 12,000$ $\mathrm{cm}^{-1}$ is assigned as the lowest-energy ${ }^{5} A \rightarrow{ }^{5} E\left(d_{\mathrm{xz}, \mathrm{yz}} \rightarrow d_{\mathrm{z}} 2\right)$ LF transition, based on its pseudo- $A$ (derivative) shape and temperature-dependent behavior. Interestingly, the sharp positive peak overlapping this band corresponds to a dip in abs. (dashed line), indicating a Fano antiresonance of this allowed ${ }^{5} E$ state with a spin-forbidden ${ }^{3} A$. Furthermore, the two different vibronic progressions associated with this ${ }^{5} E$ indicate strong spin-orbit coupling (SOC) with another nearby triplet $\left({ }^{3} E\right)$ which distorts the ${ }^{5} E$ PES. Also, from the MCD spectra the low-energy shoulder in the abs. spectrum at $20,000 \mathrm{~cm}^{-1}$ corresponds to a pronounced, negatively-signed $z$-polarized (i.e. $\mathrm{Fe}-\mathrm{O}$ ) vibronic progression with a $v_{\mathrm{Fe}-\mathrm{O}}$ of $490 \mathrm{~cm}^{-1}$, greatly reduced from that of the ground state $\left(\sim 830 \mathrm{~cm}^{-1}\right)$. These excited-state properties led to the assignment of this band as the oxo $\pi \rightarrow d_{\mathrm{xz}, \mathrm{yz}} \mathrm{CT}$ transition. Thus, spectroscopy on $\left(\mathrm{TMG}_{3}\right.$ tren $) \mathrm{Fe}^{\mathrm{IV}}=\mathrm{O}$ reveals three FMOs: the $d_{\mathrm{z}^{2}} \sigma^{*}$ ground state, the lowlying $d \pi^{*}$ and a higher-energy oxo $\pi$ FMO. $^{21}$

CASPT2 calculations reproducing these spectral features (Figure 15) were extrapolated to the $\mathrm{Fe}-\mathrm{O}$ bond length associated with the TS for $\mathrm{H}$-atom abstraction. ${ }^{21}$ These low-lying states generate (Figure 15, right) three comparable (in energy and coefficients on the oxo) FMOs - one $\sigma$ and two $\pi$ 's - with the former oriented for attack along the $\mathrm{Fe}-\mathrm{O}$ bond and the latter two oriented for perpendicular attack on substrates. Importantly, all three FMOs polarize at the TS, generating $\mathrm{Fe}^{\mathrm{III}}$ —oxyl species with high oxygen $p$ hole character for effective electrophilic reactivity.

Thus, spectroscopy correlated to electronic-structure calculations has revealed that in contrast to $\mathrm{Fe}^{\mathrm{IV}}=\mathrm{O} S=1$ species where only a $\pi$-FMO is available for electrophilic reactivity perpendicular to the $\mathrm{Fe}^{\mathrm{IV}}=\mathrm{O}$ bond, $\mathrm{Fe}^{\mathrm{IV}}=\mathrm{O} S=2$ intermediates have both $\sigma$ and $\pi$ FMOs available for reactivity, respectively along and perpendicular to the $\mathrm{Fe}^{\mathrm{IV}}=\mathrm{O}$ bond.

\subsection{Structure/Function Correlations}

\subsubsection{H-atom abstraction vs. Electrophilic aromatic substitution-(4-}

hydroxyphenyl)pyruvate dioxygenase (HPPD) and (4-hydroxy)mandelate synthase (HmaS) both react with the same substrate, (4-hydroxyphenyl)pyruvate (HPP); HPPD performs EAS on the ring, while HmaS performs H-atom abstraction (Figure 16). HPP has an a-keto acid group that binds in a bidentate mode that directly tethers this substrate to the $\mathrm{Fe}^{\mathrm{II}}$. From the CD data (with Moran and Spencer et al. ${ }^{22}$ ) in Figure 17, HPP is bound to the two Fe $\mathrm{Fe}^{\mathrm{II}}$ enzymes with different conformations of the ring, consistent with their different reaction products (Figure 16). The $\mathrm{O}_{2}$ reaction ${ }^{22}$ produces the two $\mathrm{Fe}^{\mathrm{IV}}=\mathrm{O}$ intermediates (Figure 18). For HPPD, the $\mathrm{Fe}-\mathrm{O}$ bond is oriented for $\sigma$ electrophilic attack on the aromatic ring, while 
in $\mathrm{HmaS}$ the $\mathrm{Fe}-\mathrm{O}$ bond is oriented perpendicular to the $\mathrm{H}-\mathrm{C}$ bond of the substrate and activated for $\pi \mathrm{H}$-atom abstraction. For both reaction coordinates the $\mathrm{Fe}-\mathrm{O}$ bond elongates

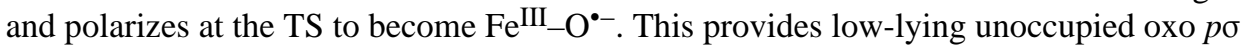
(for HPPD) and $p \pi$ (for HmaS) FMOs, leading to comparable low-energy barriers for EAS $(16 \mathrm{kcal} / \mathrm{mol}, \mathrm{HPPD})$ and $\mathrm{H}$-atom abstraction $(14 \mathrm{kcal} / \mathrm{mol}, \mathrm{HmaS}){ }^{22}$

3.2.2 Halogenation vs. Hydroxylation-For the halogenases that include SyrB2, which catalyzes the chlorination of L-Thr in syringomycin $\mathrm{E}$ biosynthesis, the carboxylate ligand of the $\mathrm{Fe}^{\mathrm{II}}$ facial triad is replaced by a halide $\left(\mathrm{Cl}^{-} / \mathrm{Br}^{-}\right) .{ }^{3}$ These halogenases bind $\mathrm{aKG}$ and react with $\mathrm{O}_{2}$ to generate an $\mathrm{Fe}^{\mathrm{IV}}=\mathrm{O}$ intermediate ${ }^{3}$ that $\mathrm{H}$-atom abstracts, and in the case of SyrB2 with its native substrate rebounds to form the halogenated product 4-Cl-L-Thr (Figure 19 , top). With the alternative substrate $\mathrm{L}-\mathrm{Nva}$ (Figure 19, bottom), the $\mathrm{Fe}^{\mathrm{IV}}=\mathrm{O}$ intermediate $\mathrm{H}$-atom abstracts but rebounds to produce a hydroxylated product. ${ }^{23}$ Thus, in complement to the studies described in section 3.2.1 where two NHFe enzymes perform different reactions with the same substrate (HPP), for the halogenases one NHFe enzyme perfoms different reactions depending on substrate.

In collaboration with Bollinger and Krebs et al. ${ }^{24}$ the first NRVS spectra of any oxygen intermediate were obtained. This $\mathrm{Fe}^{\mathrm{IV}}=\mathrm{O}$ intermediate can be generated with either $\mathrm{Cl}^{-}$or $\mathrm{Br}^{-}$bound to NHFe active site, providing an important mass perturbation on the NRVS data. The data in Figure 20 show that the $\mathrm{Fe}^{\mathrm{IV}}=\mathrm{O}$ intermediate has three dominant peaks in its NRVS spectrum at around 370,300 and $250 \mathrm{~cm}^{-1}$, and the intensity shifts from the higherenergy peaks in the $\mathrm{Cl}$ cognate into the lowest-energy peak in the $\mathrm{Br}$ cognate. These NRVS spectra and their $\mathrm{Cl} \rightarrow \mathrm{Br}$ perturbation are only reproduced with a 5C TBP structure with the $\mathrm{Fe}^{\mathrm{IV}}=\mathrm{O}$ bond defining the trigonal axis (Figure 20, bottom). This is the first direct structural insight into any $\mathrm{NHFe}^{\mathrm{IV}}=\mathrm{O}$ intermediate. ${ }^{24}$

For correlation to these data, a reaction coordinate was evaluated for SyrB2 using a computational approach calibrated by spectroscopic studies ${ }^{25}$ on the stable $\{\mathrm{FeNO}\}^{7}$ analog of the unobserved $\left\{\mathrm{FeO}_{2}\right\}^{8}$ intermediate in HPP-bound HPPD (vide supra). (Figure 21, top right) This is a 5C TBP structure consistent with the NRVS data (Figure 20), with its $\mathrm{Fe}-\mathrm{O}$ axis oriented perpendicular to the $\mathrm{H}-\mathrm{C}$ bond of the native substrate. This structure was used to evaluate the $\mathrm{H}$-atom abstraction reaction. The perpendicular orientation leads to a $\pi$ attack on the substrate and produces the $\mathrm{H}$-atom abstracted first product with the halide well-oriented for efficient rebound and the hydroxide ligand oriented away from the radical and stabilized by several hydrogen bonds (Figure 22, green).

In parallel, the $\mathrm{O}_{2}$ reaction coordinate in Figure 21 was evaluated with the alternative substrate $\mathrm{L}-\mathrm{Nva}$, where the difference in substrate hydrogen bonding to the peroxy species generated along the reaction coordinate can lead to an $\mathrm{Fe}^{\mathrm{IV}}=\mathrm{O}$ intermediate with its $\mathrm{Fe}-\mathrm{O}$ axis oriented toward the $\mathrm{H}-\mathrm{C}$ group of the substrate. ${ }^{24}$ The reaction coordinate with this orientation (Figure 22, orange) involves a $\sigma$ attack on the $\mathrm{H}-\mathrm{C}$ bond of the substrate with a comparable barrier to the native substrate. This produces a first product with the halide oriented away from the $\mathrm{C}$ radical but with the coordinated hydroxide group well-oriented for efficient rebound to form the hydroxylated product as observed (Figure 22).

As shown by our studies on the HPP-dependent enzymes and the halogenases, the $S=2$ $\mathrm{Fe}^{\mathrm{IV}}=\mathrm{O}$ intermediate provides both $\pi$ and $\sigma$ FMOs. These have different orientation dependencies, providing an active site flexibility in using this orientation to control reactivity. 


\section{Concluding Comments}

Crystallography, combined with enzymology, synthesis and kinetics have revealed important structural types of NHFe enzymes and their reactivities. These are often used as the bases for electronic structure calculations to elucidate mechanism. Here we have emphasized that experimental spectroscopy is key to bridging structure and reactivity with mechanism.

\section{Acknowledgments}

This research is funded by the National Institutes of Health (GM 40392).

\section{References}

1. Solomon EI, Brunold TC, Davis MI, Kemsley JN, Lee S-K, Lehnert N, Neese F, Skulan AJ, Yang Y-S, Zhou J. Geometric and electronic structure/function correlations in non-heme iron enzymes. Chem Rev. 2000; 100:235-349. [PubMed: 11749238]

2. Que L Jr, Ho RYN. Dioxygen Activation by Enzymes with Mononuclear Non-Heme Iron Active Sites. Chem Rev. 1996; 96:2607-2624. [PubMed: 11848838]

3. Krebs C, Galonić Fujimori D, Walsh CT, Bollinger JM. Non-heme Fe(IV)-oxo intermediates. Acc Chem Res. 2007; 40:484-492. [PubMed: 17542550]

4. Kovaleva EG, Niebergall MB, Chakrabarty S, Lipscomb JD. Finding Intermediates in the $\mathrm{O}_{2}$ Activation Pathways of Non-Heme Iron Oxygenases. Acc Chem Res. 2007; 40:475-483. [PubMed: 17567087]

5. Brown CD, Neidig ML, Lipscomb JD, Solomon EI. VTVH-MCD and DFT Studies of Thiolate Bonding to $\{\mathrm{FeNO}\}^{7} /\left\{\mathrm{FeO}_{2}\right\}^{8}$ Complexes of Isopenicillin N Synthase: Substrate Determination of Oxidase versus Oxygenase Activity in Nonheme Fe Enzymes. J Am Chem Soc. 2007; 129:74277438. [PubMed: 17506560]

6. Sono M, Roach MP, Coulter ED, Dawson JH. Heme-Containing Oxygenases. Chem Rev. 1996; 96:2841-2888. [PubMed: 11848843]

7. Pau MYM, Lipscomb JD, Solomon EI. Substrate activation for $\mathrm{O}_{2}$ reactions by oxidized metal centers in biology. Proc Natl Acad Sci USA. 2007; 104:18355-18362. [PubMed: 18003930]

8. Kemsley JN, Mitić N, Zaleski KL, Caradonna JP, Solomon EI. Circular Dichroism and Magnetic Circular Dichroism Spectroscopy of the Catalytically Competent Ferrous Active Site of Phenylalanine Hydroxylase and Its Interaction with Pterin Cofactor. J Am Chem Soc. 1999; 121:1528-1536.

9. Light KM, Hangasky JA, Knapp MJ, Solomon EI. Spectroscopic Studies of the Mononuclear Nonheme FeII Enzyme FIH: Second-Sphere Contributions to Reactivity. J Am Chem Soc. 2013; 135:9665-9674. [PubMed: 23742069]

10. Liu LV, Bell CB, Wong SD, Wilson SA, Kwak Y, Chow MS, Zhao J, Hodgson KO, Hedman B, Solomon EI. Definition of the intermediates and mechanism of the anticancer drug bleomycin using nuclear resonance vibrational spectroscopy and related methods. Proc Natl Acad Sci USA. 2010; 107:22419-22424. [PubMed: 21149675]

11. Burger RM, Peisach J, Horwitz SB. Activated Bleomycin - a Transient Complex of Drug, Iron, and Oxygen That Degrades DNA. J Biol Chem. 1981; 256:1636-1644. [PubMed: 6257682]

12. Neese F, Zaleski JM, Zaleski KL, Solomon EI. Electronic structure of activated bleomycin: Oxygen intermediates in heme versus non-heme iron. J Am Chem Soc. 2000; 122:11703-11724.

13. Kumar D, Hirao H, Shaik S, Kozlowski PM. Proton-Shuffle Mechanism of O-O Activation for Formation of a High-Valent Oxo-Iron Species of Bleomycin. J Am Chem Soc. 2006; 128:1614816158. [PubMed: 17165768]

14. Chow MS, Liu LV, Solomon EI. Further insights into the mechanism of the reaction of activated bleomycin with DNA. Proc Natl Acad Sci USA. 2008; 105:13241-13245. [PubMed: 18757754] 
15. Decker A, Chow MS, Kemsley JN, Lehnert N, Solomon EI. Direct hydrogen-atom abstraction by activated bleomycin: An experimental and computational study. J Am Chem Soc. 2006; 128:4719-4733. [PubMed: 16594709]

16. Liu LV, Hong S, Cho J, Nam W, Solomon EI. Comparison of High-Spin and Low-Spin Nonheme FeIII-OOH Complexes in O-O Bond Homolysis and H-Atom Abstraction Reactivities. J Am Chem Soc. 2013; 135:3286-3299. [PubMed: 23368958]

17. Lehnert N, Ho RYN, Que L Jr, Solomon EI. Electronic structure of high-spin iron(III)-alkylperoxo complexes and its relation to low-spin analogues: Reaction coordinate of O-O bond homolysis. $\mathrm{J}$ Am Chem Soc. 2001; 123:12802-12816. [PubMed: 11749538]

18. Rohde J-U, In J-H, Lim MH, Brennessel WW, Bukowski MR, Stubna A, Münck E, Nam W, Que L Jr. Crystallographic and Spectroscopic Characterization of a Nonheme Fe(IV)=O Complex. Science. 2003; 299:1037-1039. [PubMed: 12586936]

19. England J, Guo Y, Farquhar ER, Young VG Jr, Münck E, Que L Jr. The Crystal Structure of a High-Spin Oxoiron(IV) Complex and Characterization of Its Self-Decay Pathway. J Am Chem Soc. 2010; 132:8635-8644. [PubMed: 20568768]

20. Decker A, Rohde J-U, Klinker EJ, Wong SD, Que L Jr, Solomon EI. Spectroscopic and Quantum Chemical Studies on Low-Spin $\mathrm{Fe}^{\mathrm{IV}}=\mathrm{O}$ Complexes: Fe-O Bonding and Its Contributions to Reactivity. J Am Chem Soc. 2007; 129:15983-15996. [PubMed: 18052249]

21. Srnec M, Wong SD, England J, Que L Jr, Solomon EI. $\pi$-Frontier molecular orbitals in $S=2$ ferryl species and elucidation of their contributions to reactivity. Proc Natl Acad Sci USA. 2012; 109:14326-14331. [PubMed: 22908238]

22. Neidig ML, Decker A, Choroba OW, Huang F, Kavana M, Moran GR, Spencer JB, Solomon EI. Spectroscopic and electronic structure studies of aromatic electrophilic attack and hydrogen-atom abstraction by non-heme iron enzymes. Proc Natl Acad Sci USA. 2006; 103:12966-12973. [PubMed: 16920789]

23. Matthews ML, Neumann CS, Miles LA, Grove TL, Booker SJ, Krebs C, Walsh CT, Bollinger JM. Substrate positioning controls the partition between halogenation and hydroxylation in the aliphatic halogenase, SyrB2. Proc Natl Acad Sci USA. 2009; 106:17723-17728. [PubMed: 19815524]

24. Wong SD, Srnec M, Matthews ML, Liu LV, Kwak Y, Park K, Bell CB, Alp EE, Zhao J, Yoda Y, Kitao S, Seto M, Krebs C, Bollinger JM Jr, Solomon EI. Elucidation of the iron(IV) -oxo intermediate in the non-haem iron halogenase SyrB2. Nature. 2013 accepted. 10.1038/nature12304

25. Diebold AR, Brown-Marshall CD, Neidig ML, Brownlee JM, Moran GR, Solomon EI. Activation of a-Keto Acid-Dependent Dioxygenases: Application of an $\{\mathrm{FeNO}\}^{7} /\left\{\mathrm{FeO}_{2}\right\}^{8}$ Methodology for Characterizing the Initial Steps of $\mathrm{O}_{2}$ Activation. J Am Chem Soc. 2011; 133:18148-18160. [PubMed: 21981763]

\section{Biographies}

Ed Solomon received his Ph.D. from Princeton (with D.S. McClure) and postdoc-ed at the H.C. Ørsted Institute (with C.J. Ballhausen) and at Caltech (with H.B. Gray). He started his career at MIT in 1975 and moved to Stanford in 1982 where he is the Monroe E. Spaght Professor of Humanities and Sciences.

Kenneth Light received a B.S. and M.S. in chemistry from the Colorado School of Mines and is a PhD student at Stanford University. His research focus has included $\mathrm{Fe}^{\mathrm{II}}$ enzyme control of active site coordination and its contribution to reactivity.

Lei Liu received his B.S. in chemistry from Beijing Normal University and M.S. in chemistry from the University of British Columbia. Lei recently received his Ph.D. from Stanford Univirsity where he focused on peroxo-level intermediates in iron enzymes and models. 
Martin Srnec received his Ph.D. from Charles University in Prague and is a postdoctoral fellow at Stanford University. His major interest is in metalloenzymatic reaction mechanisms.

Shaun Wong received his B.S. in chemistry from UC Berkeley and his Ph.D. from Stanford University. His work centered on elucidating the electronic structures and reaction mechanisms of low-and high-spin Fe(IV)-oxo species in enzymes and model complexes. 


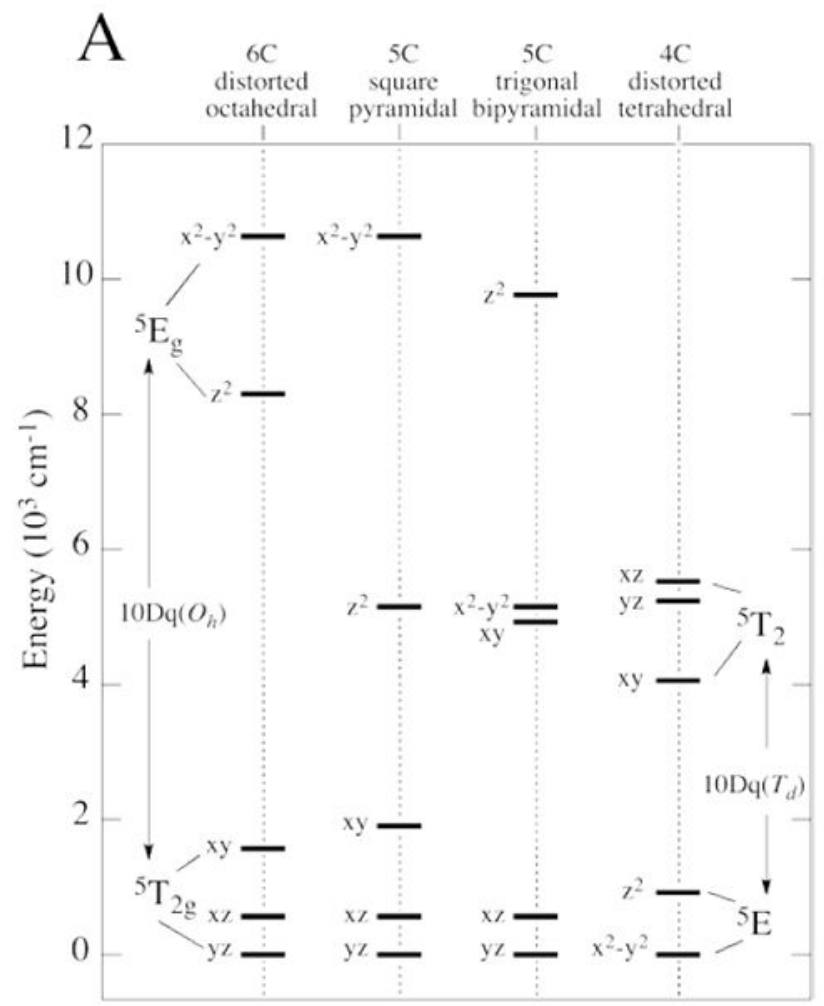

B

FIGURE 1.

NIR MCD transitions for NHFe ${ }^{\mathrm{II}}$ sites. (A) Theoretical $d$ orbital splittings for various geometries. (B) Experimentally-observed transitions. 
A

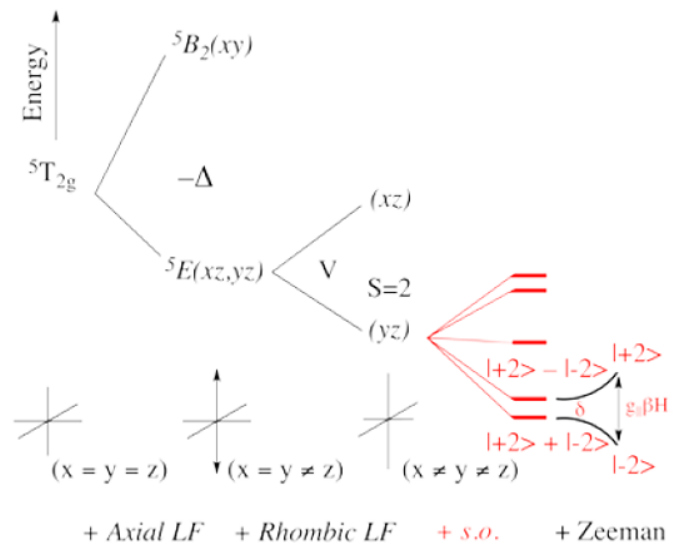

B

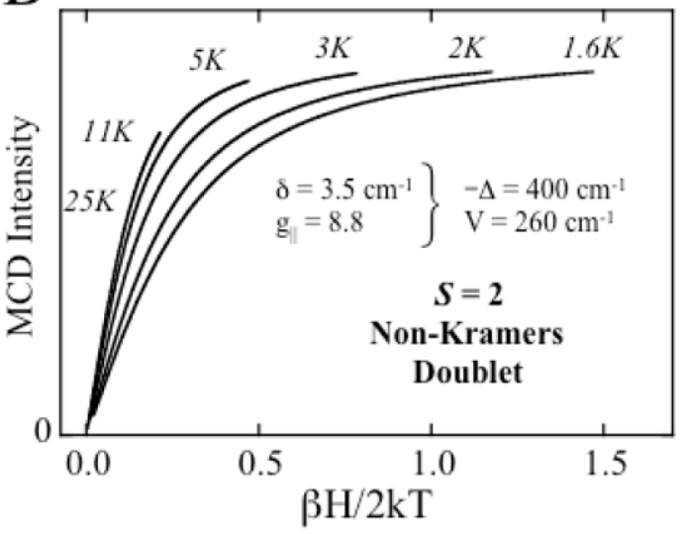

FIGURE 2.

VTVH MCD for Fe ${ }^{\mathrm{II}}$ sites. (A) Splitting of the ${ }^{5} T_{2 \mathrm{~g}}$ ground state upon axial and rhombic perturbations. S.O. Refers to the effect of spin-orbit coupling. (B) Nested MCD isotherms for an $S=2$ non-Kramers doublet. 

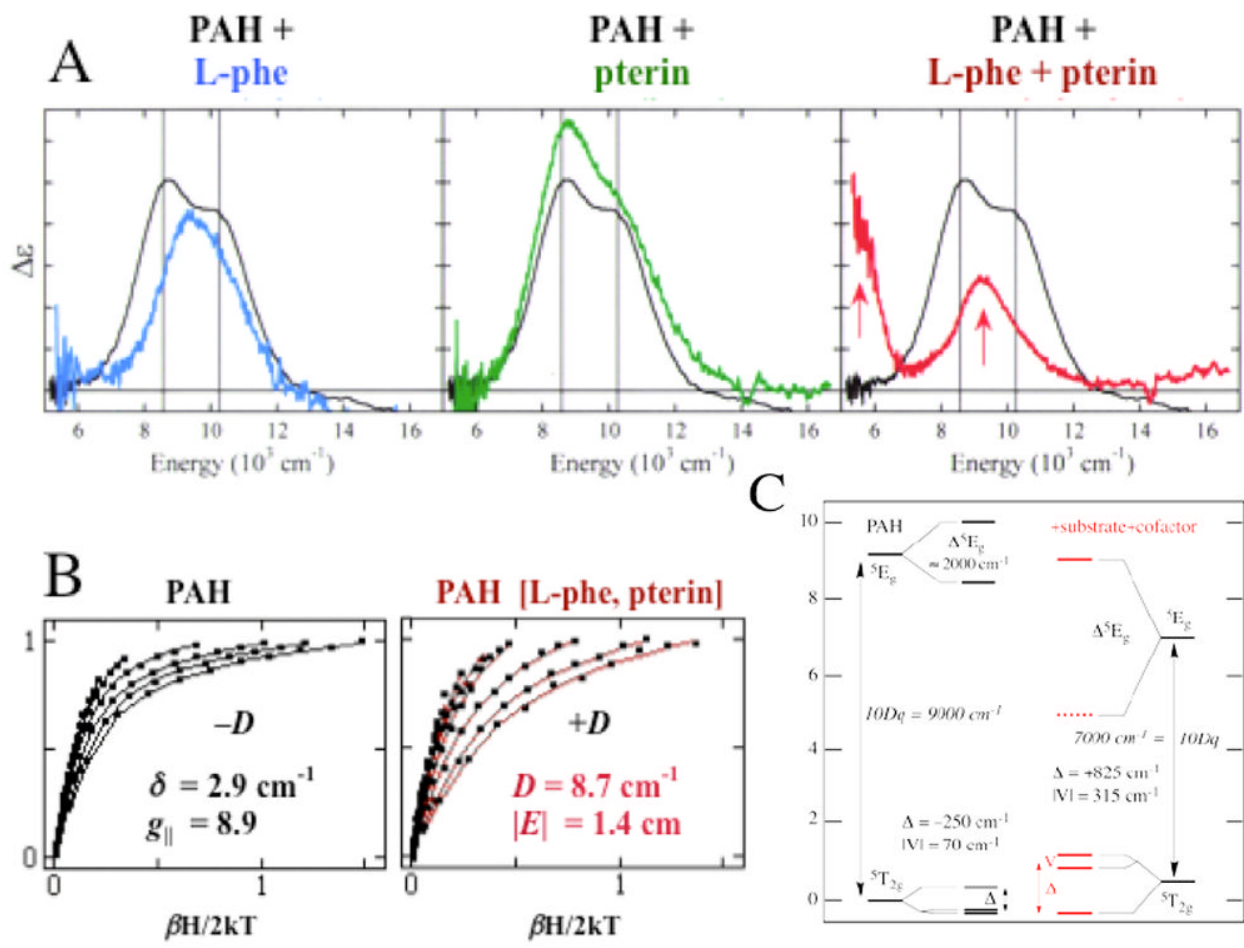

FIGURE 3.

MCD studies of PAH. (A) MCD spectra of resting PAH (black) with substrate-bound (blue), pterin-bound (green) and substrate/pterin-bound (red). All spectra were collected at $5 \mathrm{~K}$. (B) VTVH MCD data for resting (left) and substrate/pterin-bound (right) PAH. (C) Derived $d$ orbital energy level diagrams. 


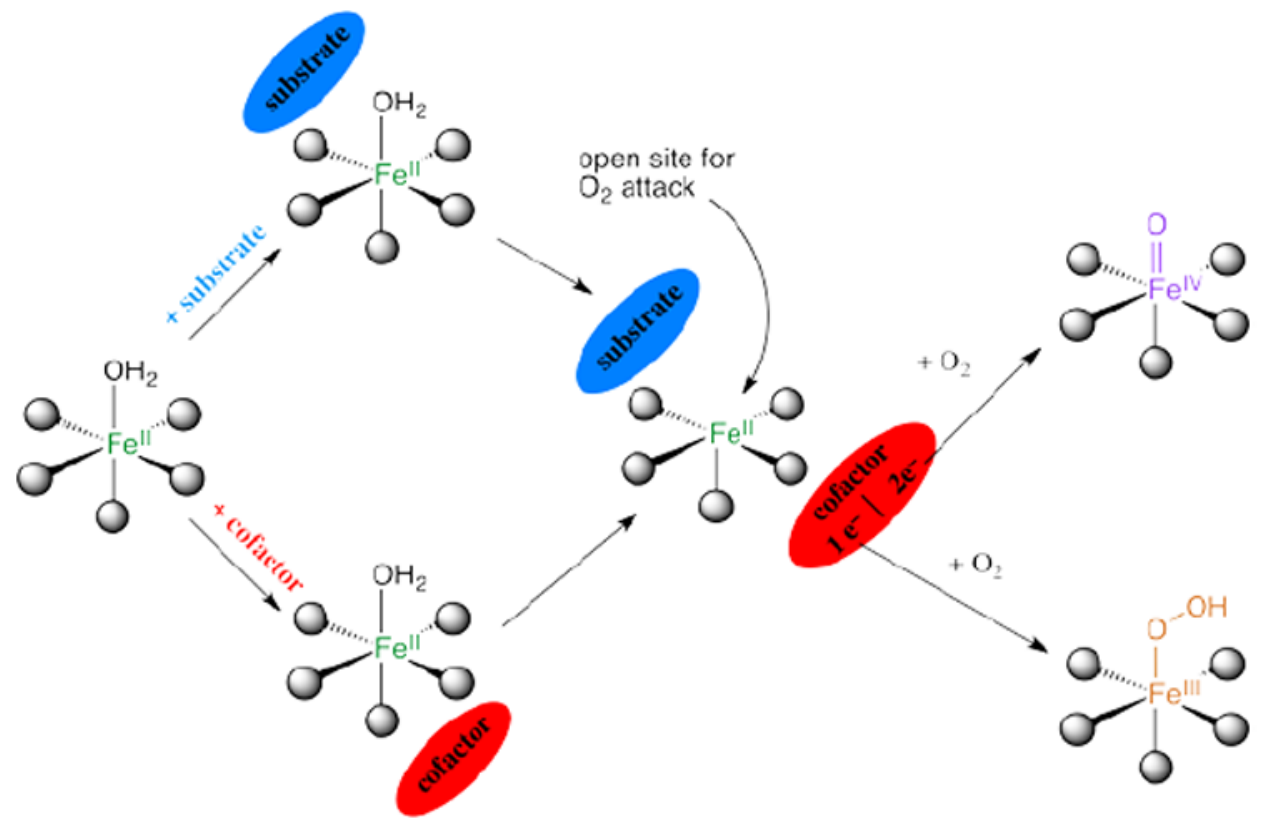

FIGURE 4.

General mechanistic strategy for $\mathrm{O}_{2}$-activation by $\mathrm{NHFe}^{\mathrm{II}}$ enzymes. 
A
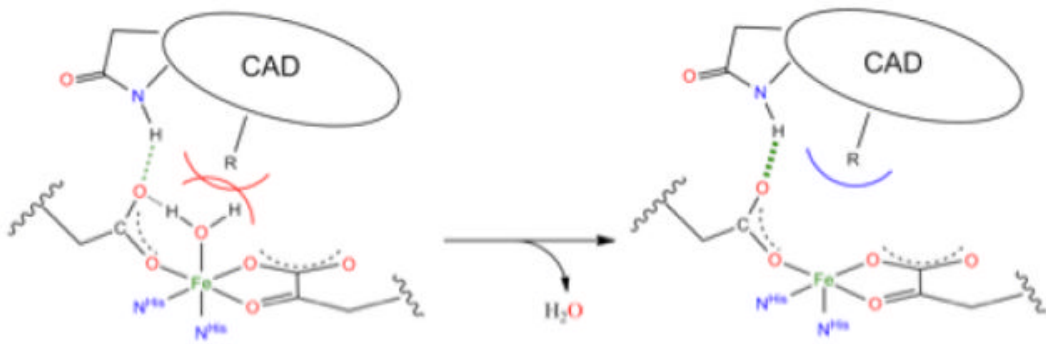

B
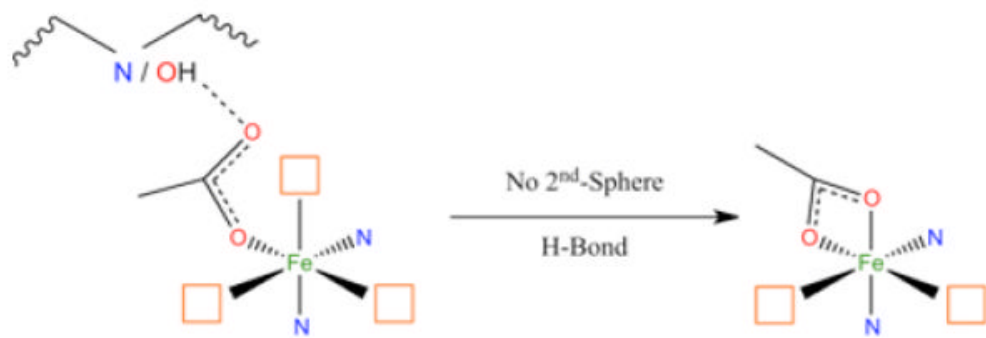

FIGURE 5.

(A) Steric and H-bonding contributions to loss of coordinated $\mathrm{H}_{2} \mathrm{O}$. CAD stands for Cterminal activation domain of the substrate HIF-1a. (B) Effect of a second-sphere Hbonding partner on the facial triad carboxylate. 
Fe: green, C:grey, N: blue, O:red, H: white

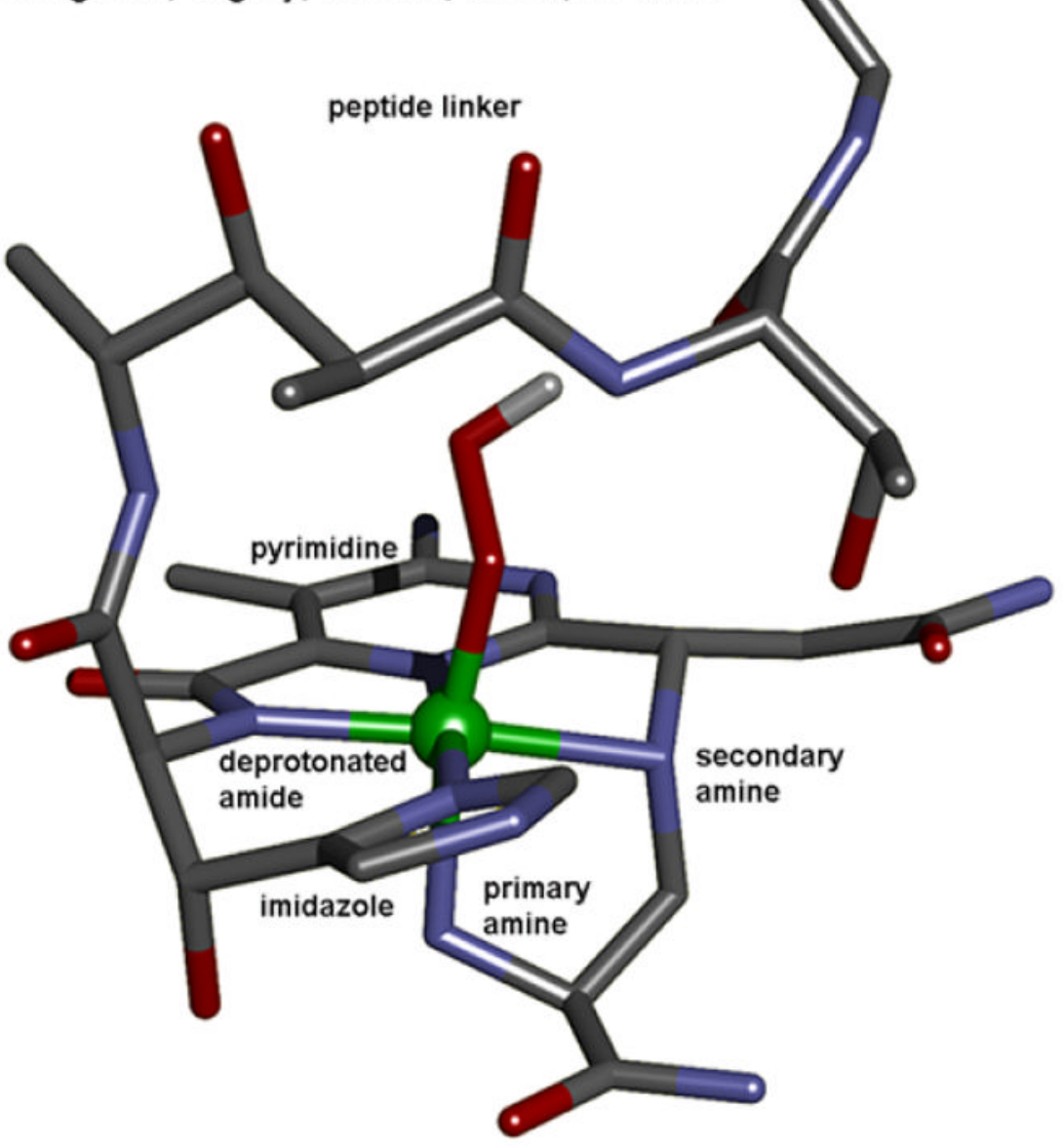

FIGURE 6.

Optimized structure of ABLM. 


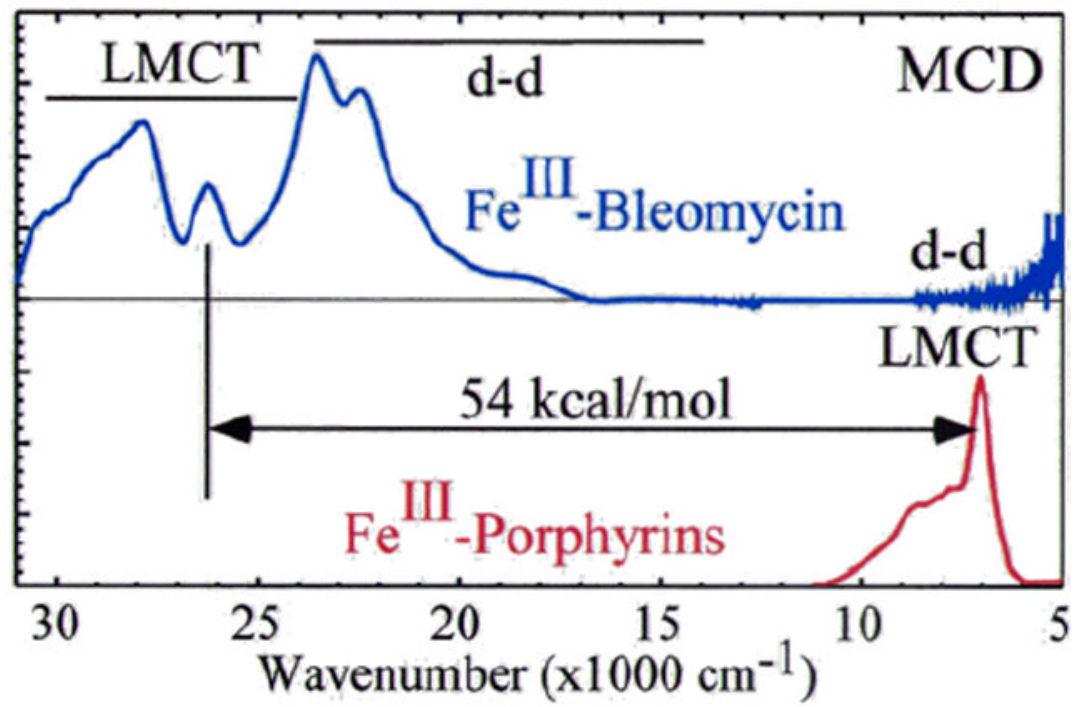

FIGURE 7.

MCD spectral comparison of LMCT energies of (BLM)Fe $\mathrm{Fe}^{\mathrm{III}}$ (deprotonated amide to $\mathrm{Fe}^{\mathrm{III}}$ ) and a prototypical $\mathrm{Fe}^{\mathrm{III}}$-heme (porphyrin to $\mathrm{Fe}^{\mathrm{III}}$ ). 


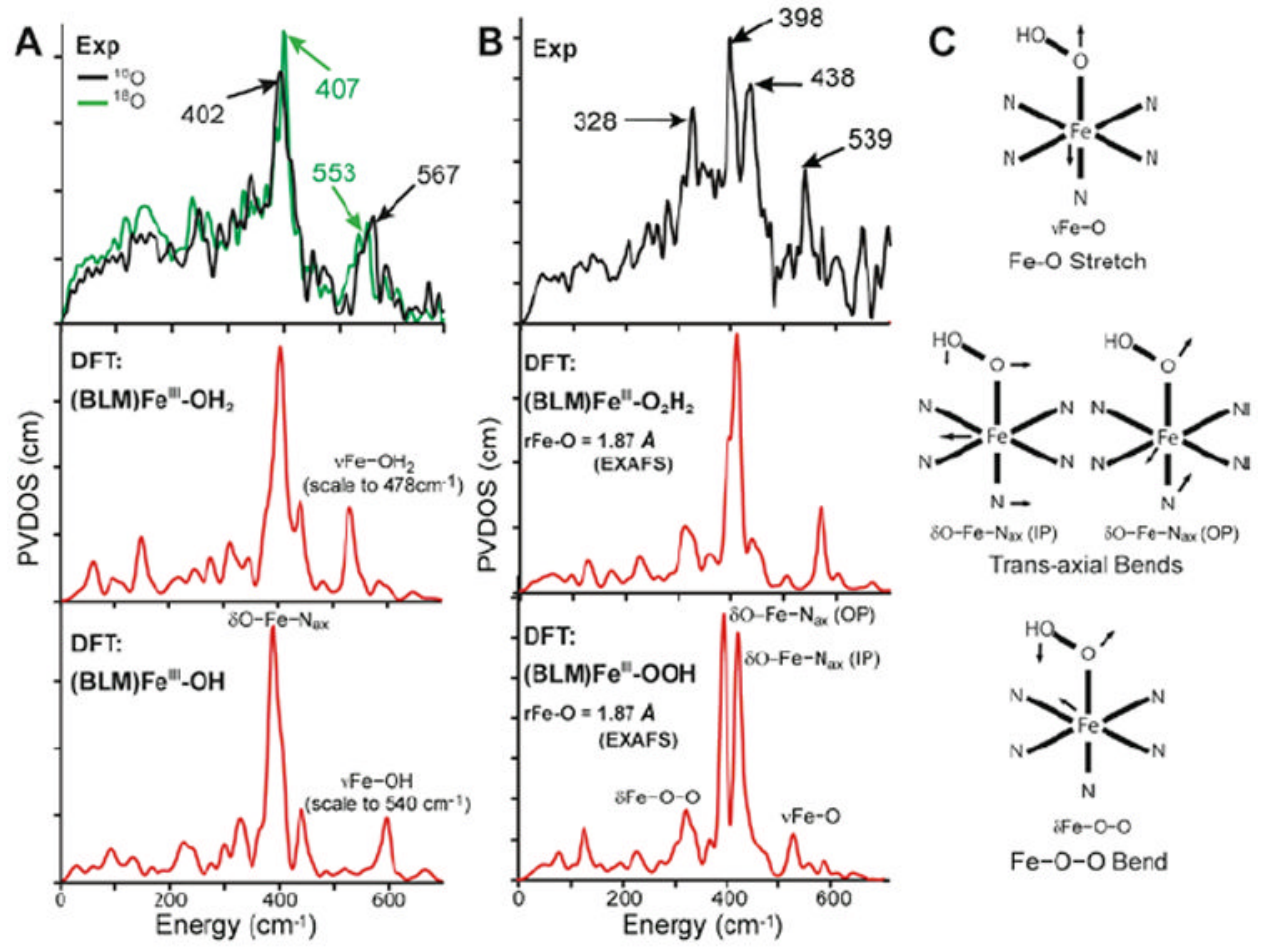

FIGURE 8.

(A) NRVS spectra (PVDOS) of ${ }^{16} \mathrm{O}$ and ${ }^{18} \mathrm{O}$ (BLM)Fe $\mathrm{Fe}^{\mathrm{III}}$ (top) and DFT-simulated PVDOS spectra of two models with $\mathrm{H}_{2} \mathrm{O}$ (middle) and $\mathrm{OH}^{-}$(bottom) as axial ligands. (B) NRVS spectrum of ABLM (top) and DFT-simulated spectra with $\mathrm{H}_{2} \mathrm{O}_{2}$ (middle) and $\mathrm{OOH}^{-}$ (bottom) as axial ligands. (C) Major NRVS-active vibrational modes of ABLM. 

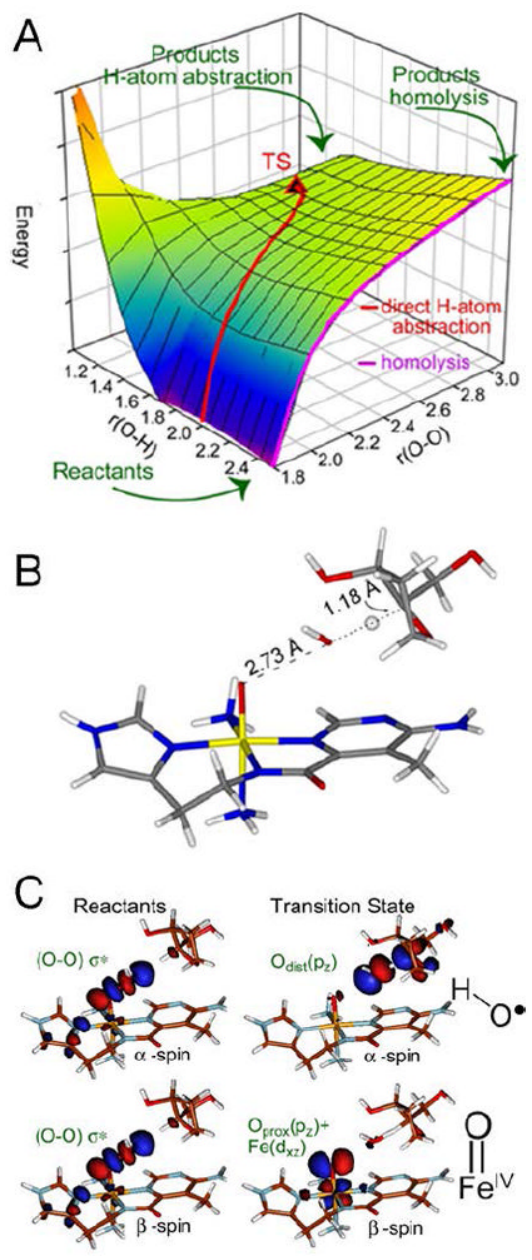

FIGURE 9.

(A) PES for H-atom abstraction by ABLM. (B) TS of direct H-atom abstraction. (C) FMOs of ABLM before (left) and at the TS (right). 

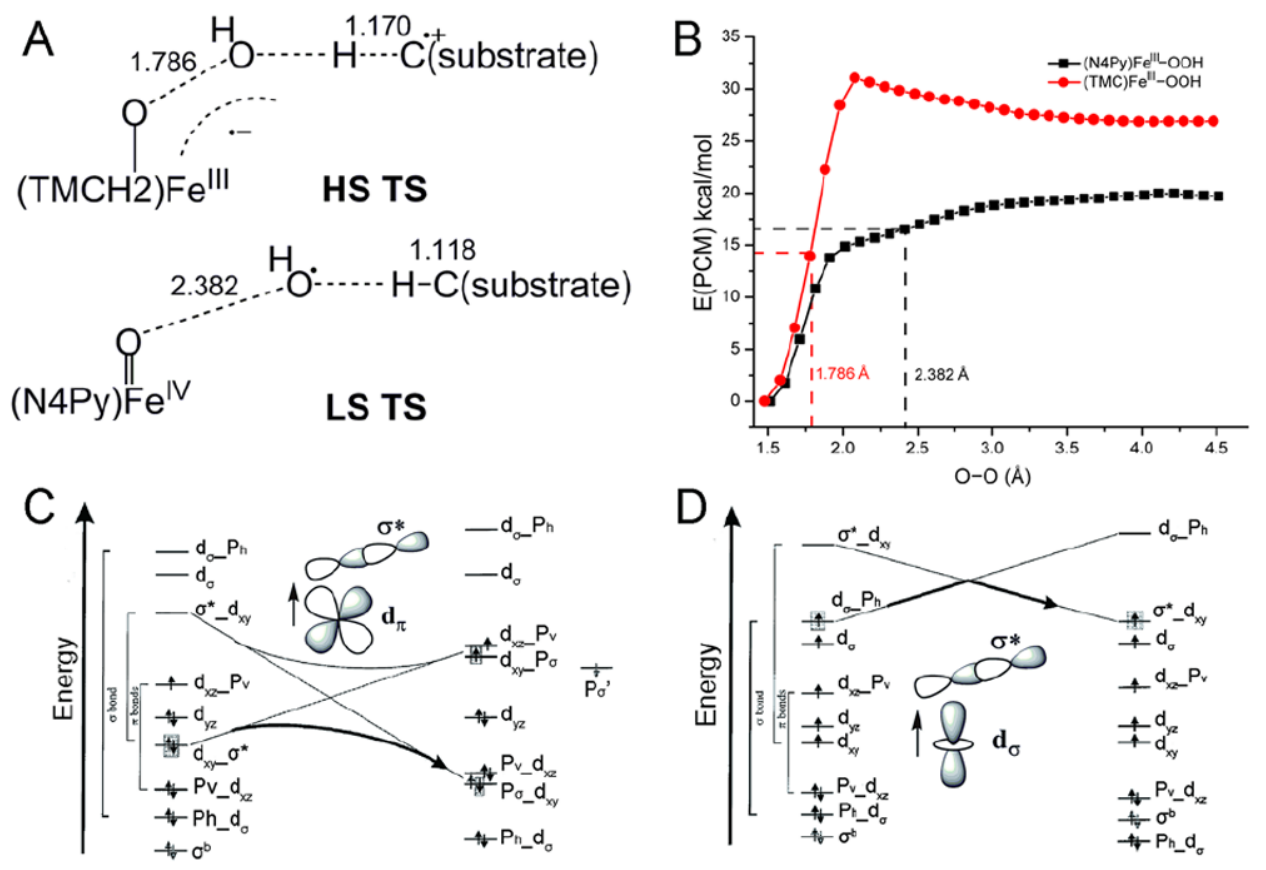

FIGURE 10.

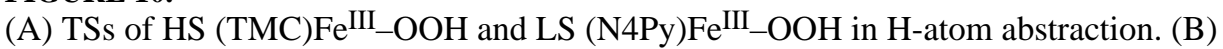
PESs of HS (TMC)Fe ${ }^{\mathrm{III}}-\mathrm{OOH}$ and LS (N4Py)Fe ${ }^{\mathrm{III}}-\mathrm{OOH} \mathrm{O}-\mathrm{O}$ homolysis. Calculations were performed using the Polarizable Continuum Model (PCM) with a dielectric constant of acetone. (C) and (D) Forbidden and allowed orbital crossings for $\mathrm{O}-\mathrm{O}$ bond homolysis of LS and HS Fe ${ }^{\mathrm{III}}$-alkylperoxo complexes. (See Ref 17 for details) 


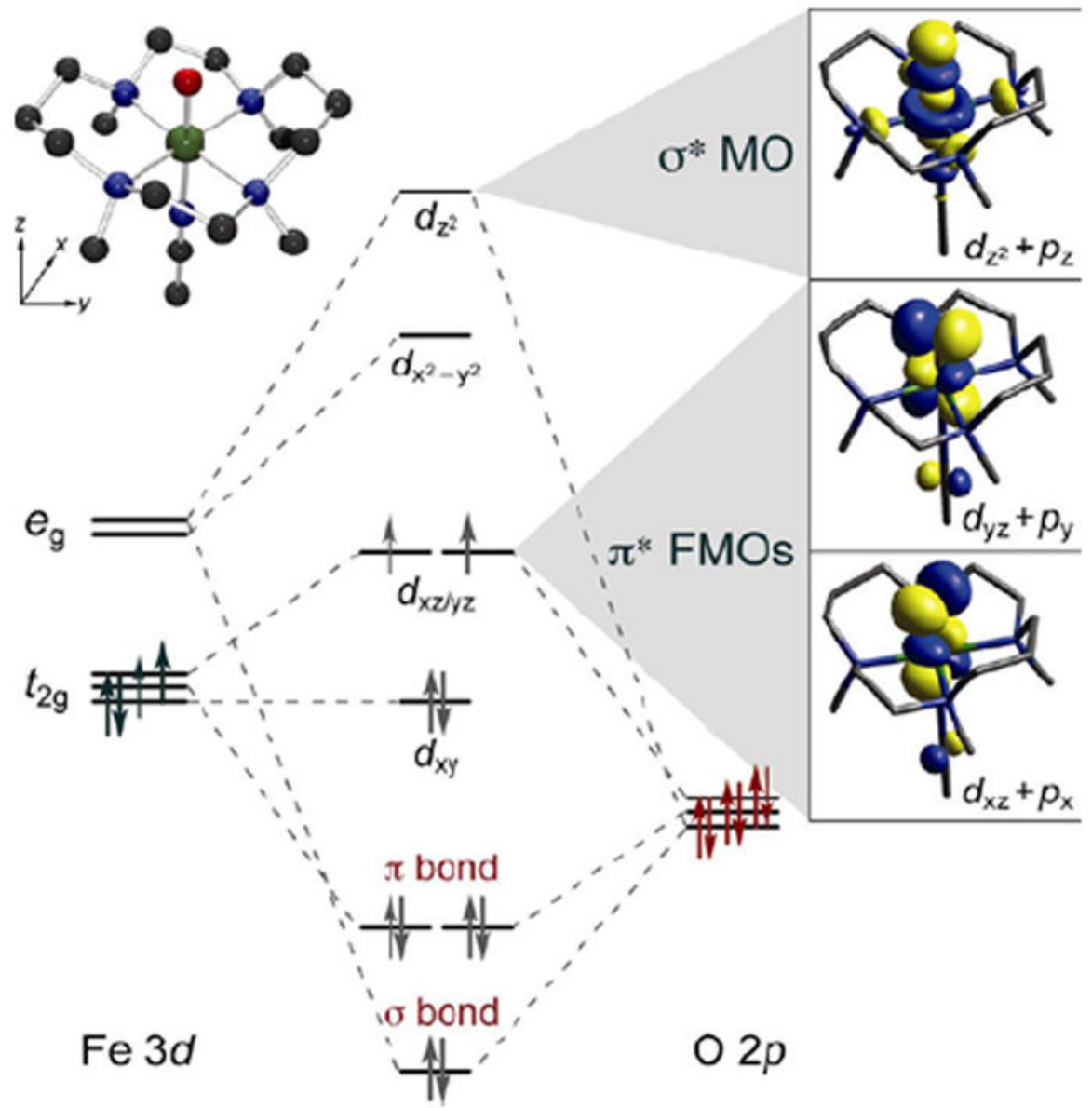

FIGURE 11.

MO diagram for $S=1$ (TMC) $\mathrm{Fe}^{\mathrm{IV}}=\mathrm{O}$ (inset, top left) producing $\pi^{*}$ FMOs and $\sigma^{*} \mathrm{MO}$ (right). 


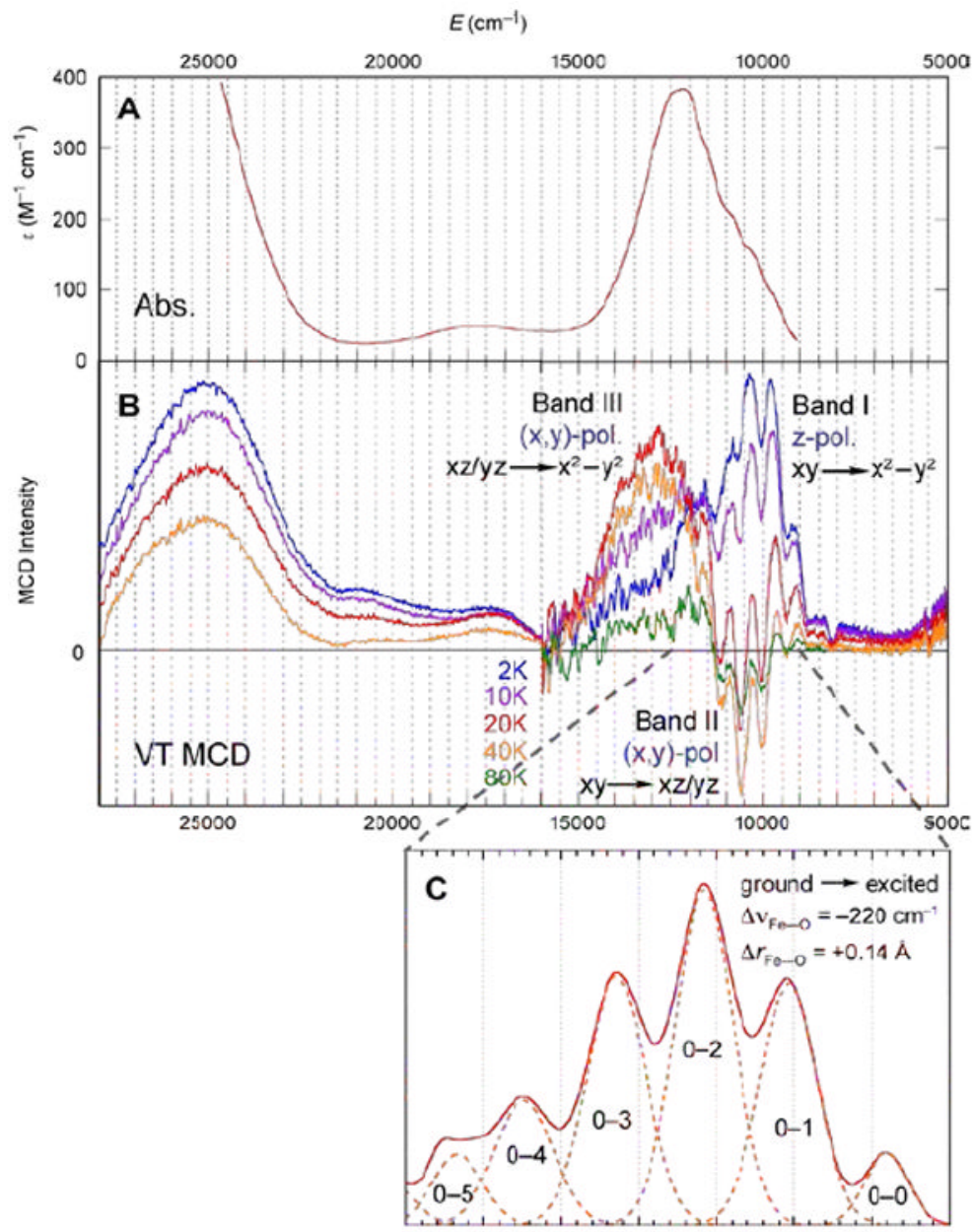

FIGURE 12.

(A) $233 \mathrm{~K}$ Abs. and (B) VT MCD spectra of $(\mathrm{TMC}) \mathrm{Fe}^{\mathrm{IV}}=\mathrm{O}$. (C) Vibronic progression of band II (40 K; plotted positive). 


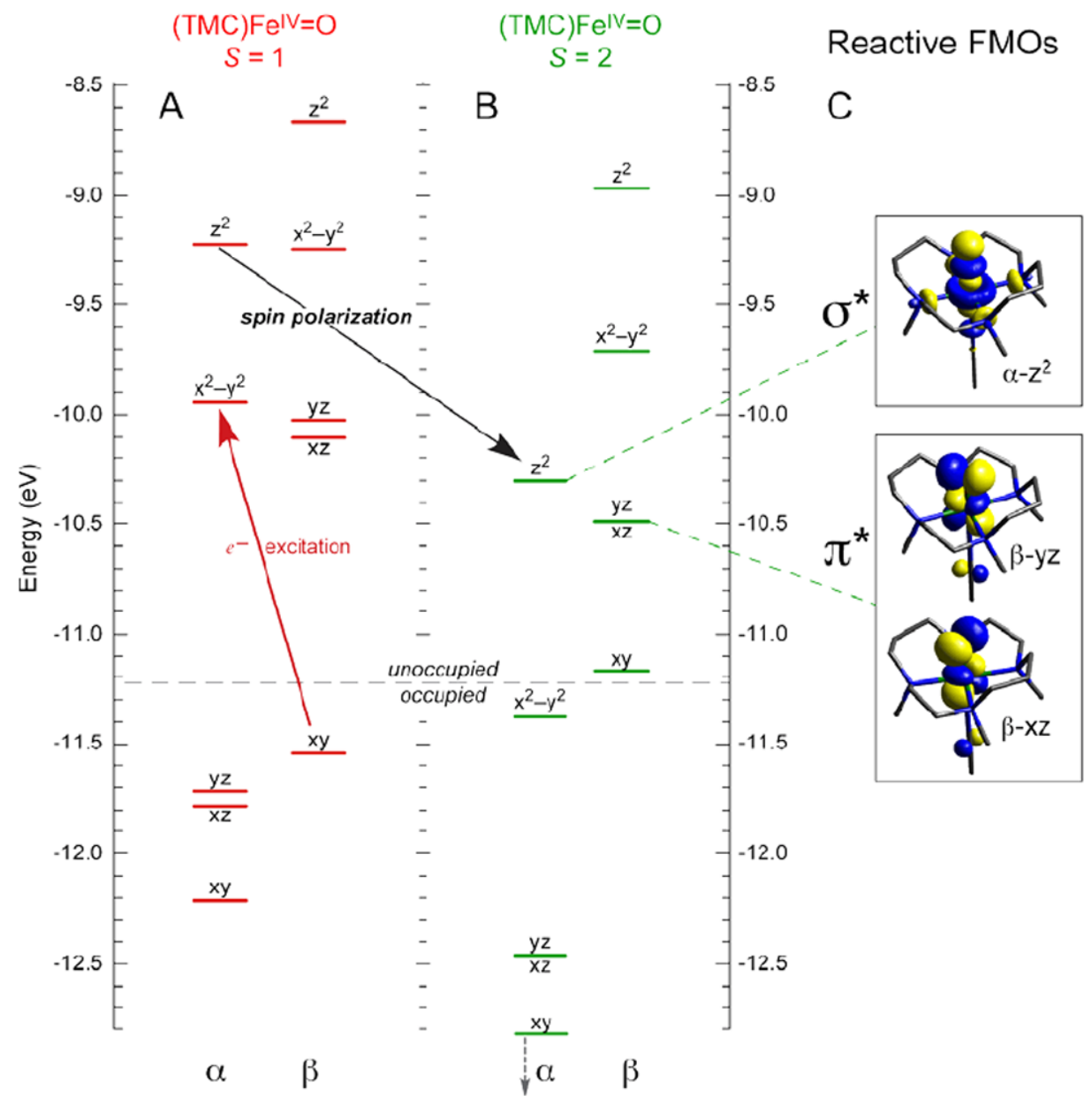

FIGURE 13.

MO diagrams of (TMC)Fe ${ }^{\mathrm{IV}}=\mathrm{O}$ in (A) $S=1$ (ground) and (B) $S=2$ states, showing that excitation of $\beta-d_{\mathrm{xy}} e^{-}$into $\mathrm{a}-d_{\mathrm{x}}{ }^{2}-\mathrm{y}^{2}$ orbital leads to spin-polarization of the a-manifold and a low-energy $a-d_{\mathrm{z}} 2$ FMO for reactivity. (C) Isosurface plots of $\mathrm{S}=2$ FMOs. 


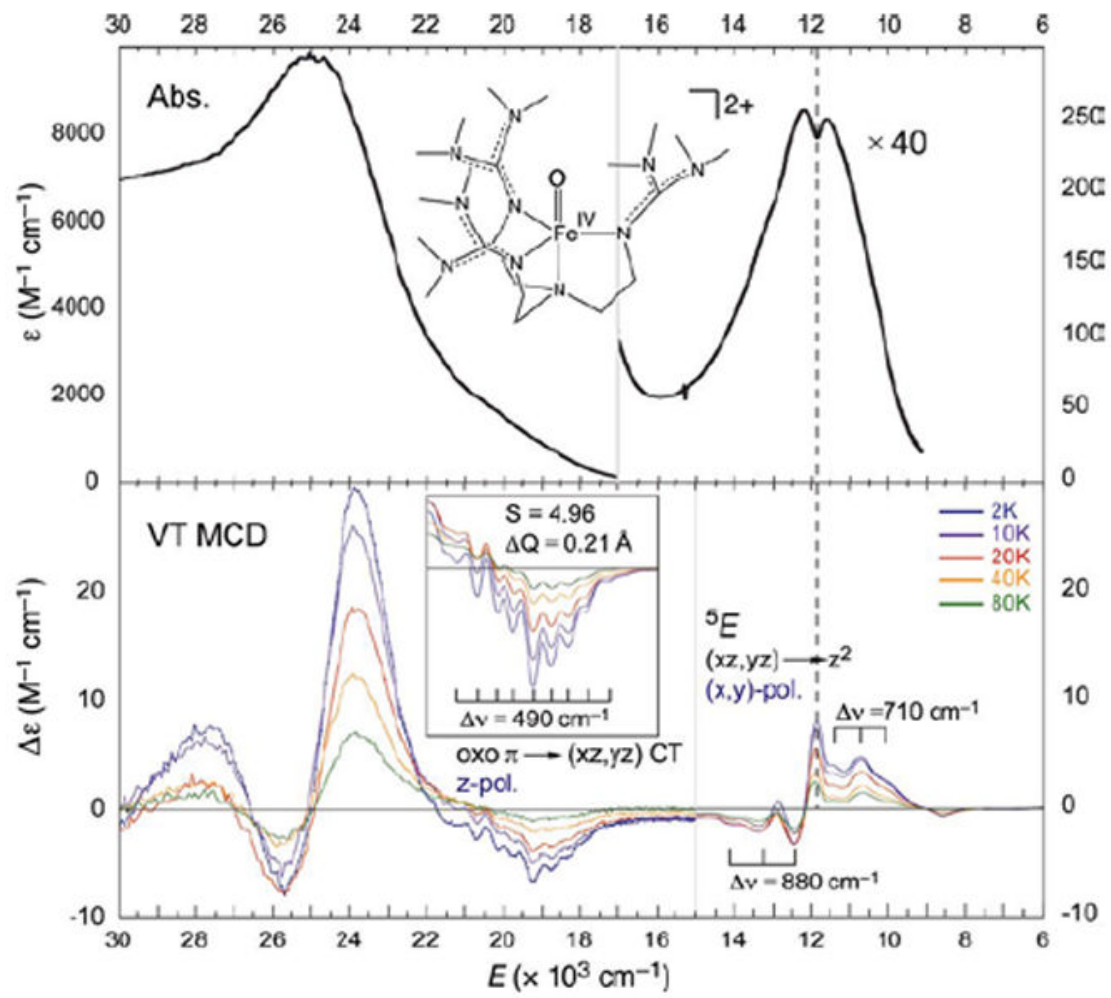

FIGURE 14.

$233 \mathrm{~K}$ Abs. (top) and VT MCD (7T, bottom) spectra of $\left(\mathrm{TMG}_{3}\right.$ tren $) \mathrm{Fe}^{\mathrm{IV}}=\mathrm{O}$ showing structured features corresponding to FMOs. 


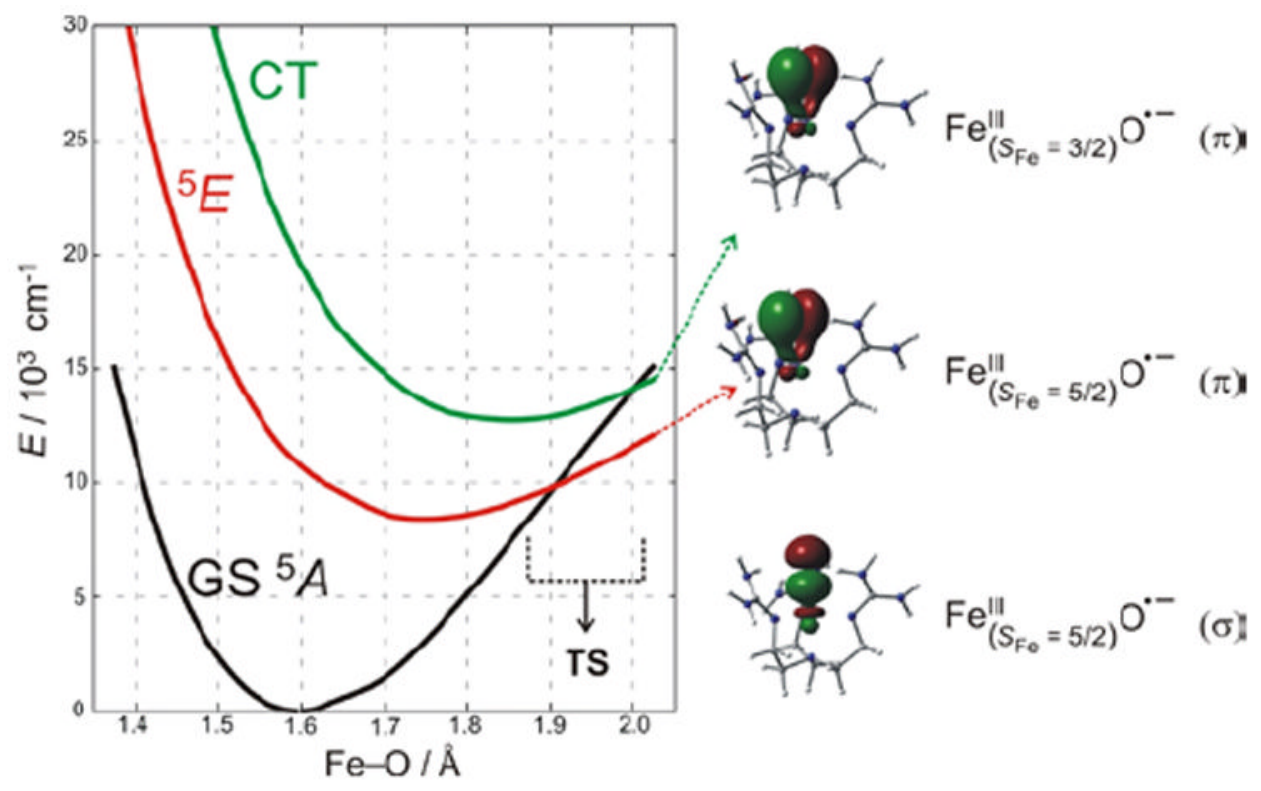

FIGURE 15.

(left) PES of $S=2$ states along the $\mathrm{Fe}-\mathrm{O}$ coordinate for $\left(\mathrm{TMG}_{3}\right.$ tren $) \mathrm{Fe}^{\mathrm{IV}}=\mathrm{O}$, which lead to one $\sigma$ and two $\pi$ FMOs of $\mathrm{Fe}^{\mathrm{III}}$ —oxyl character (right) at the TS. 


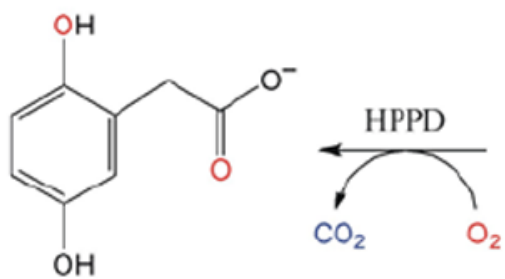

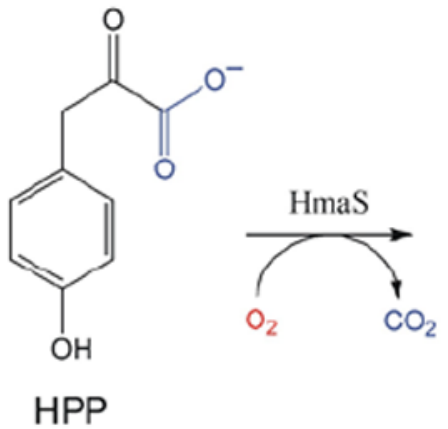<smiles>O=C([O-])[C@H](O)c1ccc(O)cc1</smiles>

FIGURE 16.

Reactions of HPP with HPPD (left, EAS) and HmaS (right, H-atom abstraction) to produce homogentisate and (4-hydroxy)mandelate respectively. 


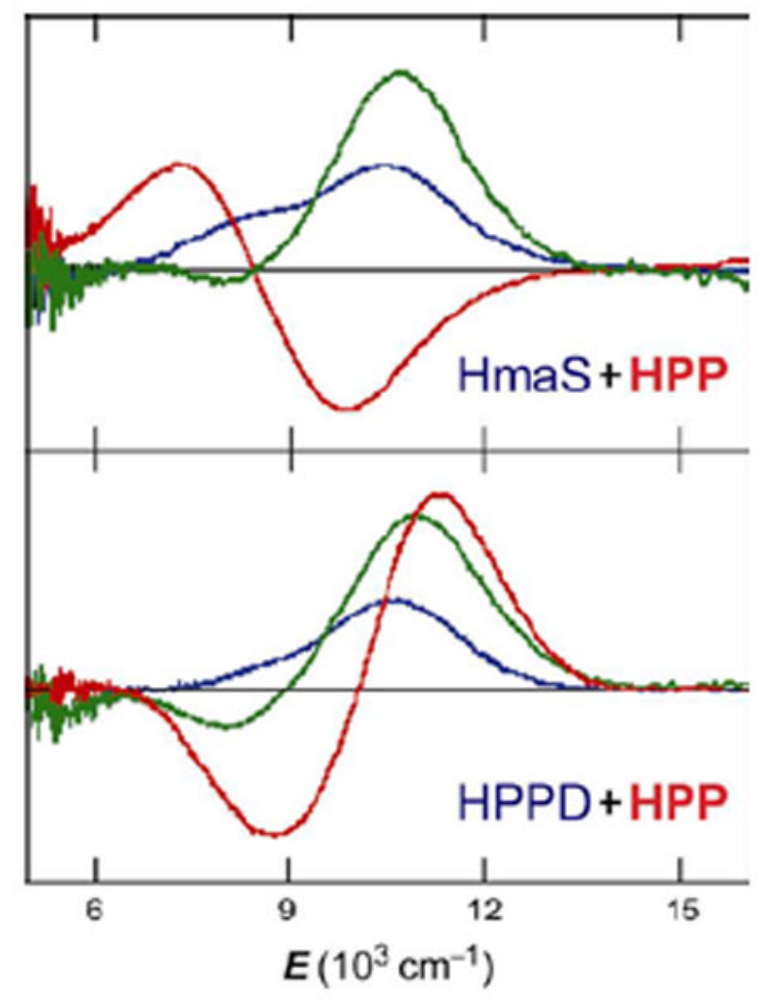

FIGURE 17.

CD spectra of HPP binding (red lines) to HmaS (top) and HPPD (bottom) $\mathrm{Fe}^{\mathrm{II}}$ sites. Resting $\mathrm{Fe}^{\mathrm{II}} d-d$ transitions (blue), and pyruvate-bound-Fe $\mathrm{F}^{\mathrm{II}}$ (green) as controls. 


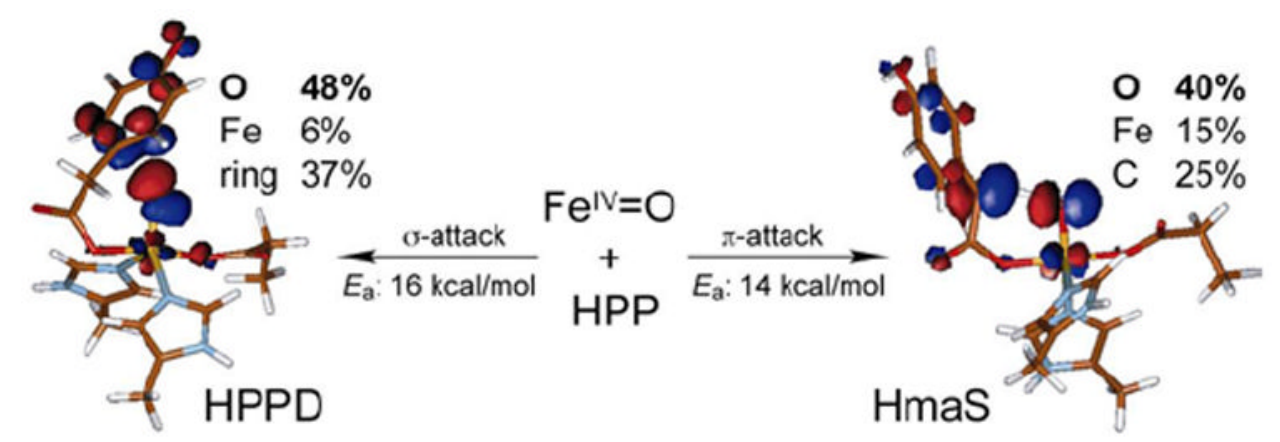

FIGURE 18.

Reactivities of $\mathrm{Fe}^{\mathrm{IV}}=\mathrm{O}$ intermediates in HPPD (left) and $\mathrm{HmaS}$ (right), with different substrate (HPP) conformations leading to a $\sigma$ TS for EAS in HPPD and a $\pi$ TS for $\mathrm{H}$-atom abstraction in HmaS. Formation of $\mathrm{Fe}^{\mathrm{III}}-\mathrm{O}^{\bullet-}$ species at TS provides FMOs primed for reactivity. 

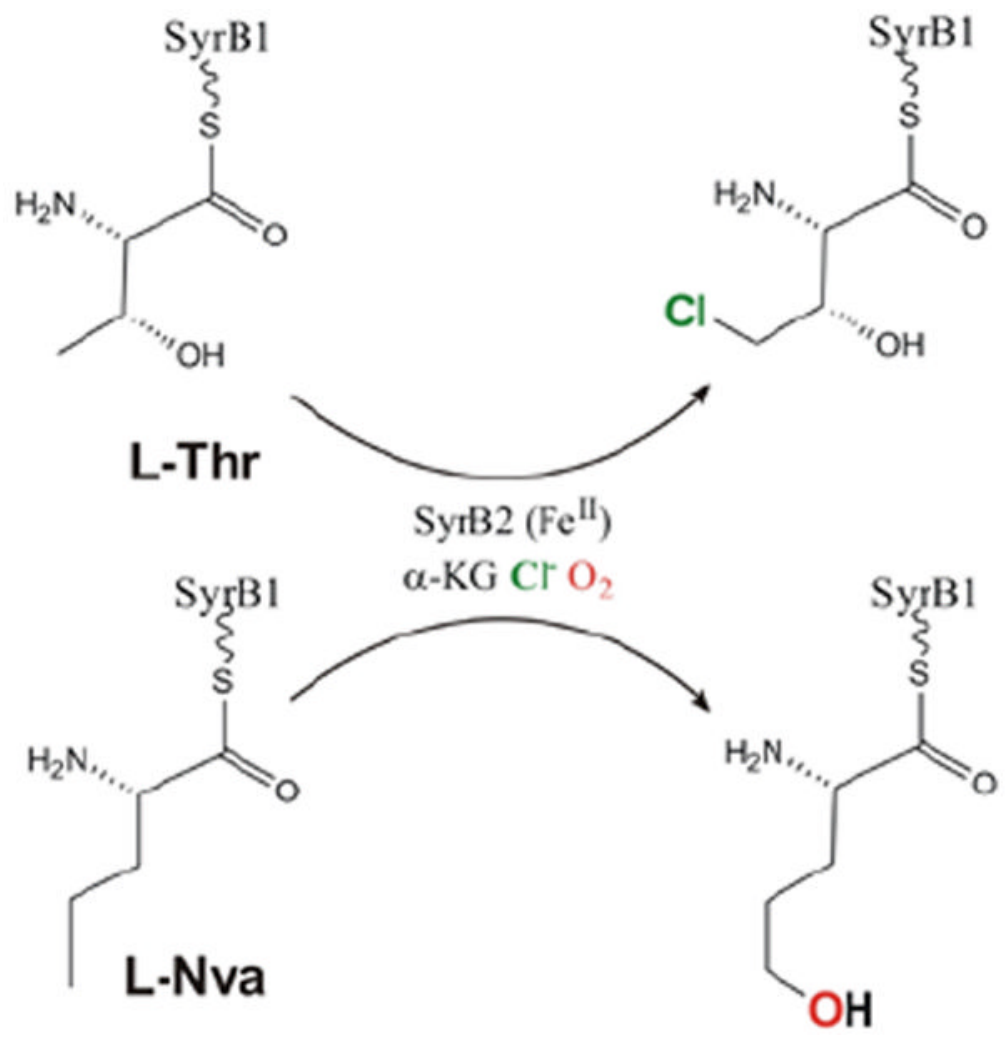

FIGURE 19.

SyrB2 catalyzes both chlorination of native substrate ${ }_{\mathrm{L}}-\mathrm{Thr}$ (top) and hydroxylation of alternative substrate $\mathrm{L}-\mathrm{Nva}$ (bottom). 


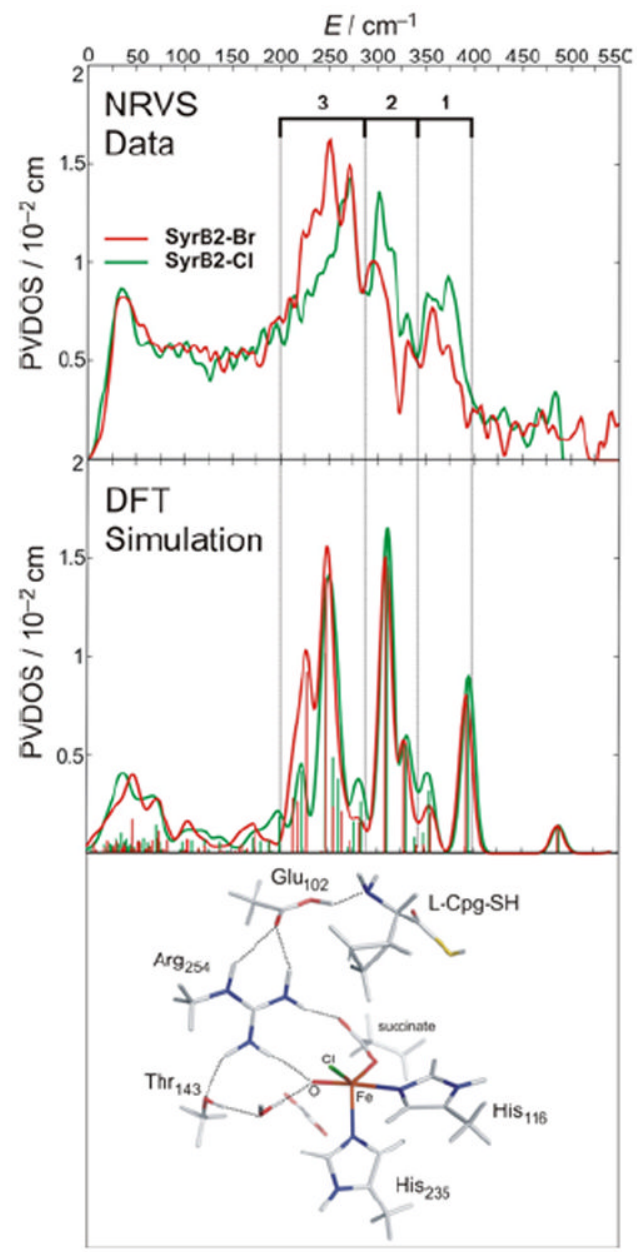

FIGURE 20.

Experimental (top) and simulated (middle) NRVS spectra of $\mathrm{Fe}^{\mathrm{IV}}=\mathrm{O}$ intermediate of SyrB2, ligated at $\mathrm{Fe}^{\mathrm{IV}}=\mathrm{O}$ active site by either $\mathrm{Cl}^{-}$(green) or $\mathrm{Br}^{-}($red $)$. Simulated spectra based on TBP structure with inert substrate ${ }_{\mathrm{L}}-\mathrm{Cpg}$ (bottom). 

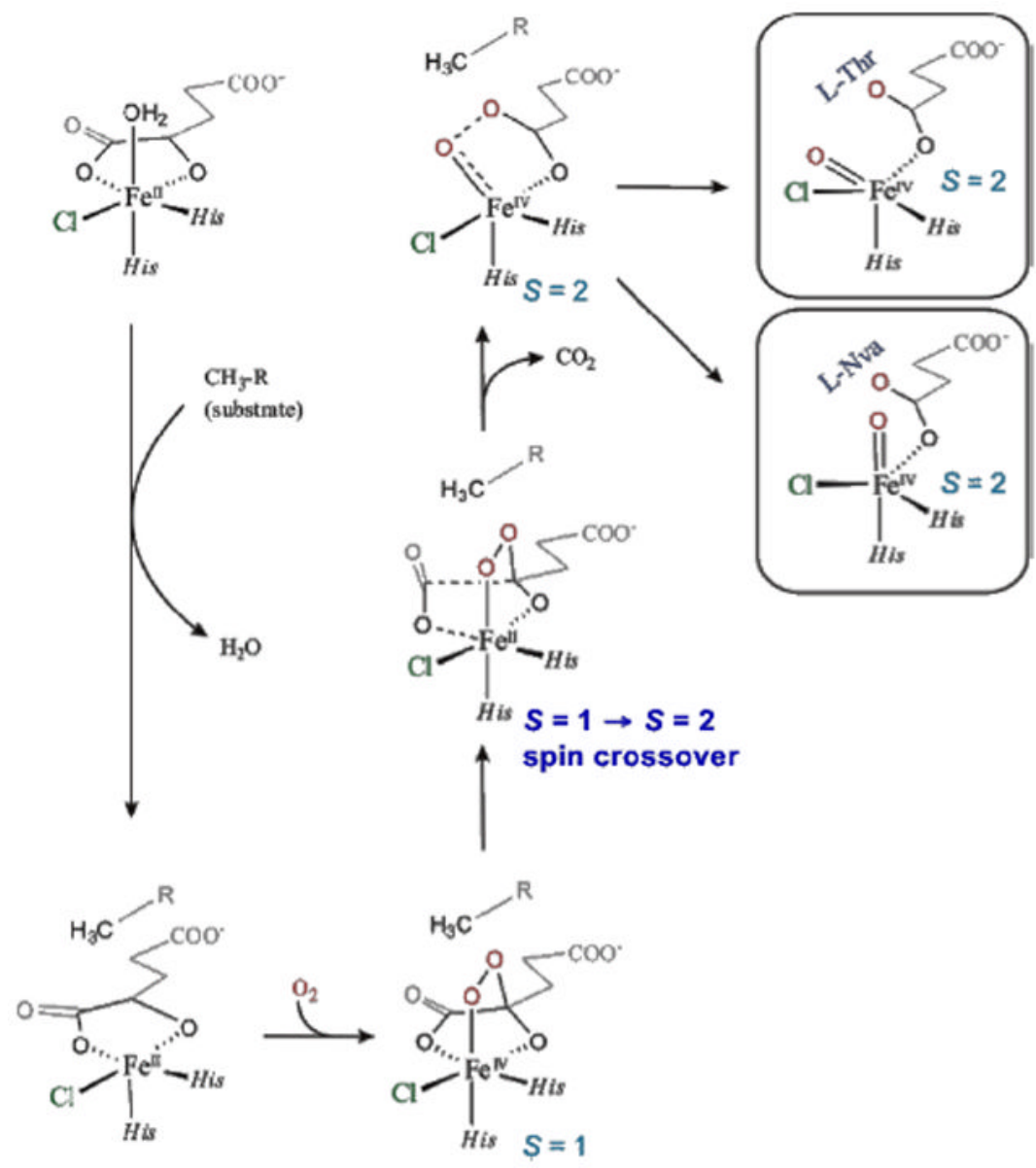

FIGURE 21.

$\mathrm{O}_{2}$ activation in SyrB2 leading to two $\mathrm{Fe}^{\mathrm{IV}}=\mathrm{O}$ intermediate orientations relative to substrate (right): perpendicular (native ${ }_{\mathrm{L}}-\mathrm{Thr}$ ) and parallel (non-native ${ }_{\mathrm{L}}-\mathrm{Nva}$ ). 


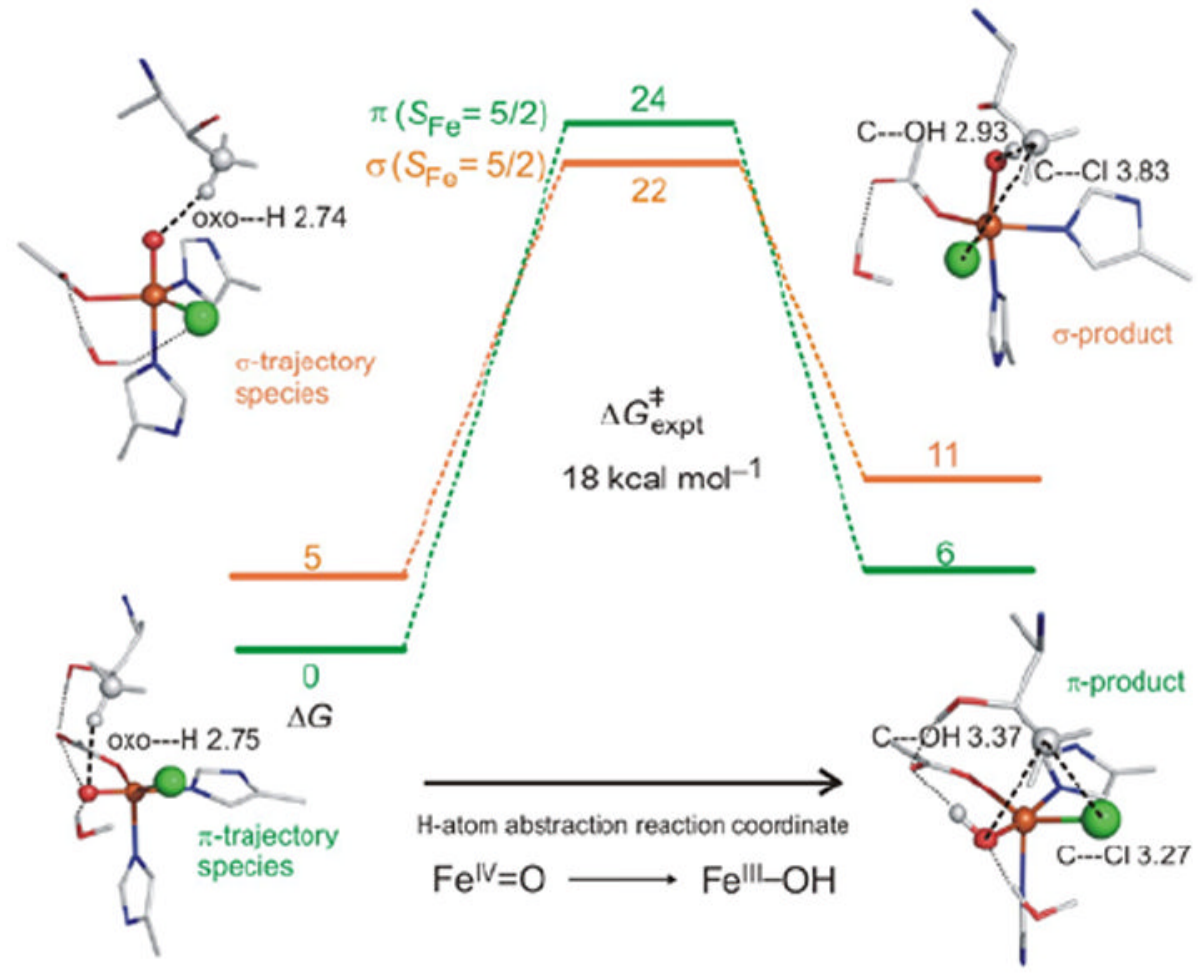

FIGURE 22.

SyrB2 $\mathrm{H}$-atom abstraction reaction coordinates for $\pi$-trajectory (green) and $\sigma$-trajectory (orange). 
TABLE 1

NHFe enzymes.

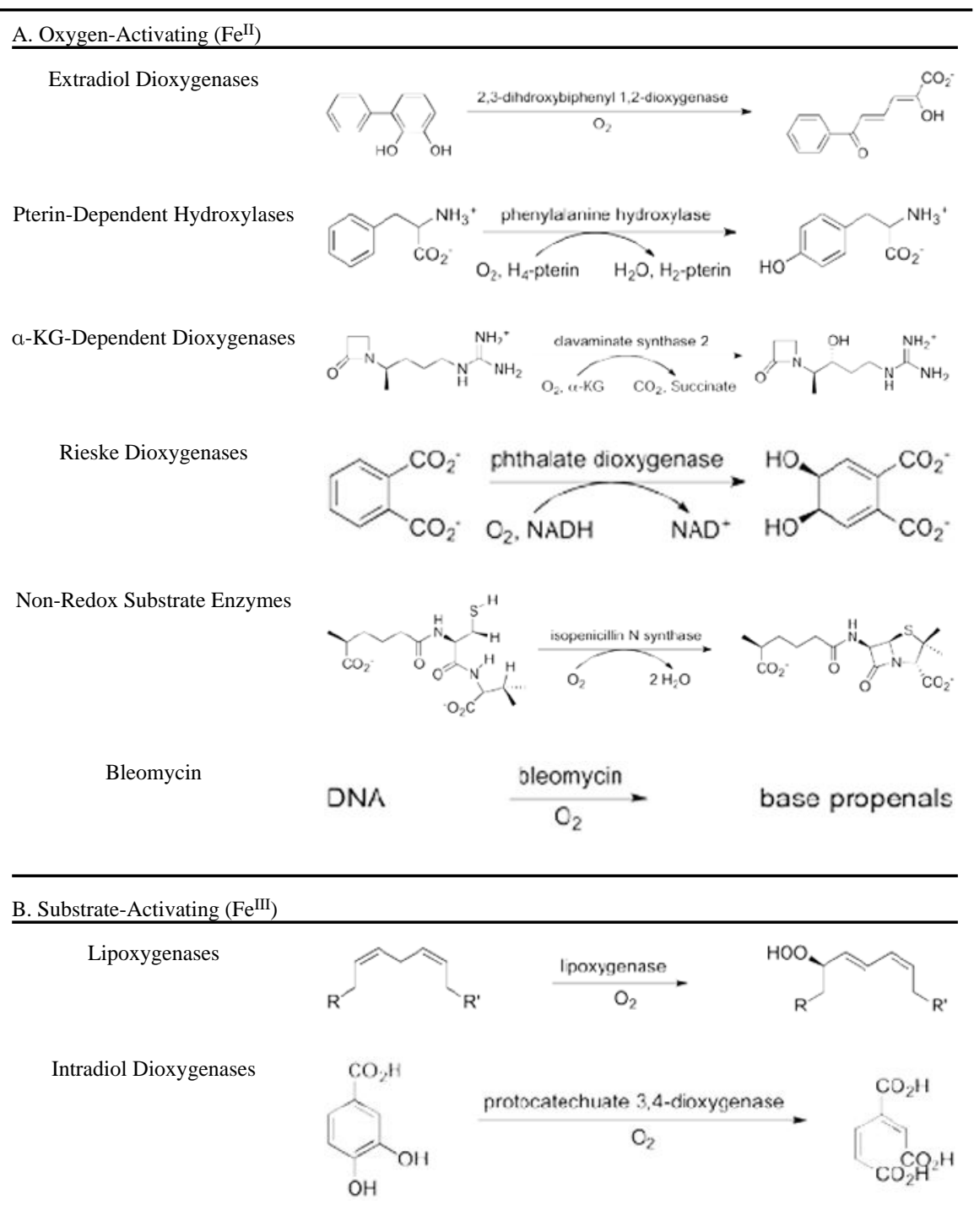


TABLE 2

Thermodynamics of heterolytic cleavage of $\mathrm{O}-\mathrm{O}$ bonds in $\mathrm{P} 450$ and ABLM and direct $\mathrm{H}$-atom abstraction by ABLM.

\begin{tabular}{|l|l|l|l|l|}
\hline \multirow{2}{*}{ Reactant } & \multicolumn{4}{|c|}{ Thermodynamics (kcal/mol) } \\
\cline { 2 - 5 } & $\Delta \boldsymbol{E}$ & $\Delta \boldsymbol{E}($ solv $)$ & $-\boldsymbol{T} \Delta S$ & $\Delta \boldsymbol{G}$ \\
\hline $\mathrm{Fe}^{\mathrm{III}}(\mathbf{P o r})\left(\mathbf{S C H}_{3}\right)-\mathbf{O O H}$ Heterolytic & -75 & -52 & -6 & -58 \\
\hline $\mathrm{Fe}^{\mathrm{III}}(\mathbf{B L M})-\mathbf{O O H}$ Heterolytic & +99 & +20 & -7 & +13 \\
\hline $\mathbf{F e}^{\mathrm{III}}(\mathbf{B L M})-\mathbf{O O H}$ Direct H-atom & +13 & +9 & -16 & -7 \\
\hline
\end{tabular}

